\title{
WestVirginiaUniversity
}

THE RESEARCH REPOSITORY @ WVU

Graduate Theses, Dissertations, and Problem Reports

2006

\section{Livestock and dairy producers' knowledge of quality assurance issues}

Andrea L. Flanagan

West Virginia University

Follow this and additional works at: https://researchrepository.wvu.edu/etd

\section{Recommended Citation}

Flanagan, Andrea L., "Livestock and dairy producers' knowledge of quality assurance issues" (2006).

Graduate Theses, Dissertations, and Problem Reports. 2356.

https://researchrepository.wvu.edu/etd/2356

This Thesis is protected by copyright and/or related rights. It has been brought to you by the The Research Repository @ WVU with permission from the rights-holder(s). You are free to use this Thesis in any way that is permitted by the copyright and related rights legislation that applies to your use. For other uses you must obtain permission from the rights-holder(s) directly, unless additional rights are indicated by a Creative Commons license in the record and/ or on the work itself. This Thesis has been accepted for inclusion in WVU Graduate Theses, Dissertations, and Problem Reports collection by an authorized administrator of The Research Repository @ WVU. For more information, please contact researchrepository@mail.wvu.edu. 


\title{
Livestock and Dairy Producers' Knowledge of Quality Assurance Issues
}

Andrea L. Flanagan

Thesis submitted to the Davis College of Agriculture, Forestry, and Consumer Sciences at West Virginia University in partial fulfillment of the requirements for the degree of

\author{
Master of Science \\ in \\ Agricultural and Extension Education \\ Harry N. Boone, Jr., Ph.D., Chair \\ Deborah A. Boone, Ph.D. \\ Robert A. Dailey, Ph.D. \\ Phillip I. Osborne, Ph.D.
}

Division of Resource Management

\author{
Morgantown, West Virginia \\ 2006
}

Keywords: Agricultural and Extension Education, Beef, Beef Quality Assurance, Dairy Quality Assurance 


\begin{abstract}
Livestock and Dairy Producers' Knowledge of Quality Assurance Issues.
\end{abstract}

Andrea L. Flanagan

The purpose of this study was to determine the level of knowledge and use of quality assurance practices by dairy and beef producers in West Virginia and to determine if differences in the level of use existed between D/BQA certified producers and non-certified producers. The population consisted of 125 West Virginia dairy producers identified on a Health Department list of regulated dairy farms within the state and 2,720 West Virginia beef producers from a database comprised of WV BQA certified producers and the South Branch and Buckhannon Stockyards mailing lists. A random sample of 92 dairy producers and 340 beef producers were randomly selected from the accessible population. Two-hundred and two producers responded to the survey. A descriptive research design was used for this study. It was found that producers certified in the WV D/BQA program were more knowledgeable of quality assurance issues such as prevention of injection-site lesions, adequate recordkeeping, and vaccination guidelines than their non-certified counterparts. Producers certified in the program were also found to be more likely to adopt certain quality assurance practices. 


\section{ACKNOWLEDGEMENTS}

To the members of my committee, Dr. Robert A. Dailey, Dr. Harry N. Boone Jr., Dr. Deborah A. Boone, and Dr. Phil Osborne, your knowledge and expertise enabled me to complete this research project.

Special thanks to the beef and dairy producers who took time out of their busy schedules to participate in this study. The information that you have provided gives great insight into what producers really think of the D/BQA program and what needs still have to be met.

To the Animal \& Veterinary Sciences administrative staff, Gretchen Riggs, Lindsey Triplett, Bonnie Wood, and Kim Mouser, for your cooperation, patience, and efficiency in helping me with the materials needed to get this survey sent out.

To my family and friends, Alex Baer, and the O'Dell family, I am blessed to have people like you standing behind me. Thank you for interest, encouragement, and patience. I never would have made it without you. 


\section{TABLE OF CONTENTS}

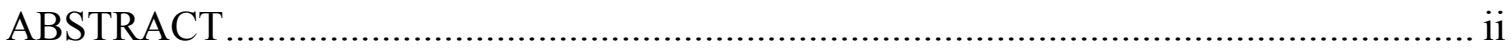

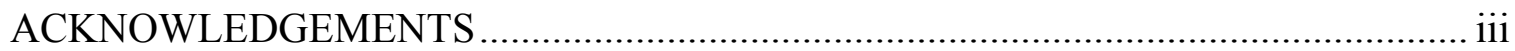

TABLE OF CONTENTS................................................................................. iv

LIST OF TABLES ...................................................................................... viii

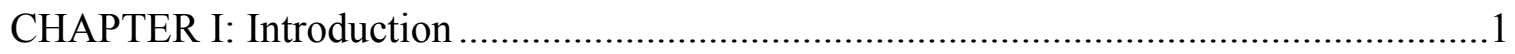

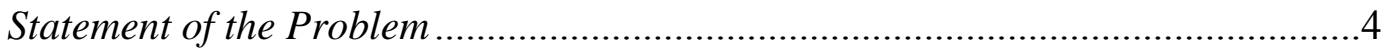

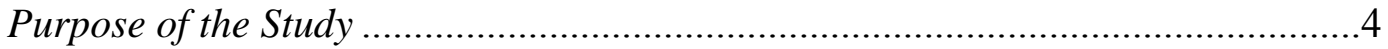

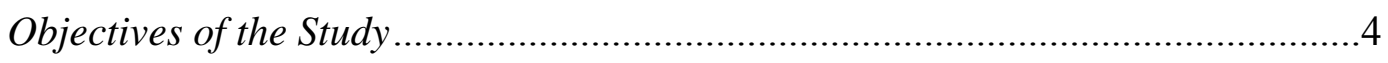

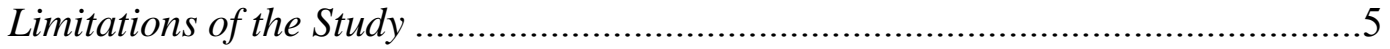

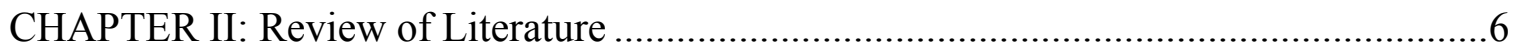

History of the Dairy/Beef Quality Assurance Program .......................................6

Influence of HACCP ................................................................................6

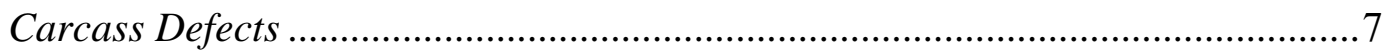

Importance of Dairy Cattle Component ........................................................

Research on Quality Assurance Programs ...................................................... 10

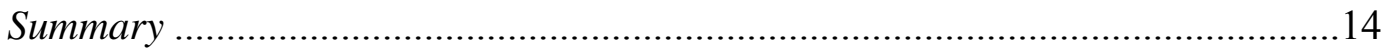

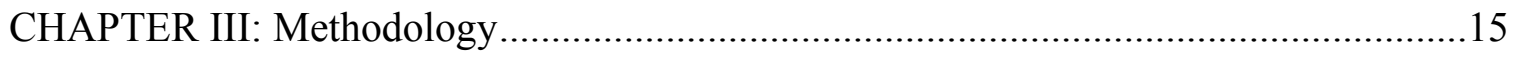

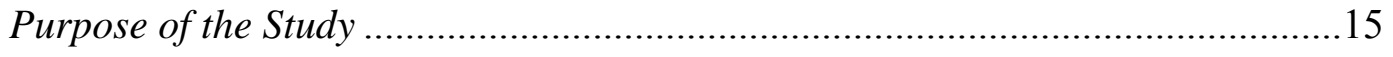

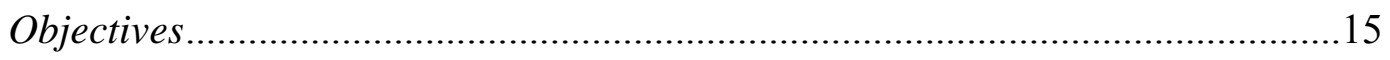

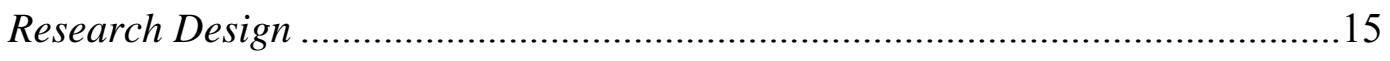

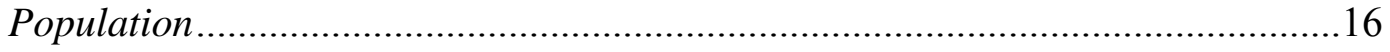


Instrumentation

Validity of Instrument .......................................................................... 18

Reliability of Instrument ………………..................................................19

Data Collection Procedures ........................................................................19

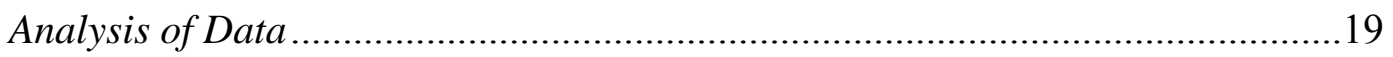

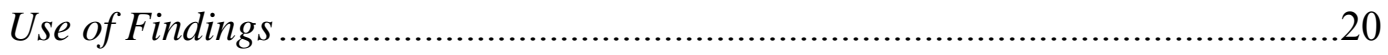

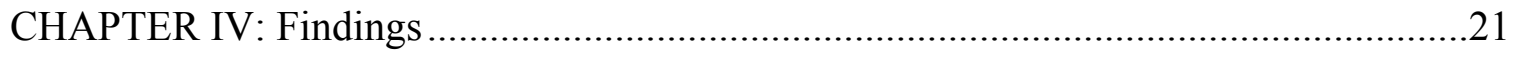

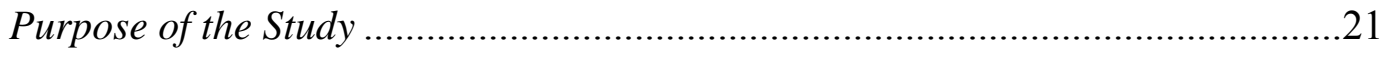

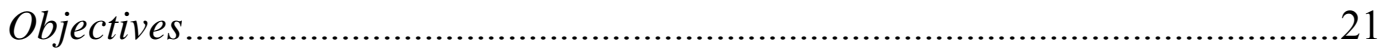

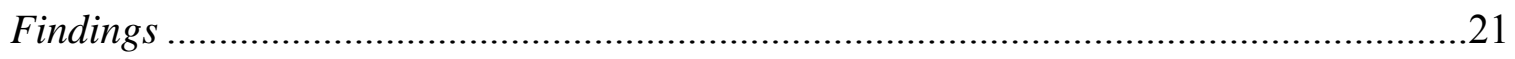

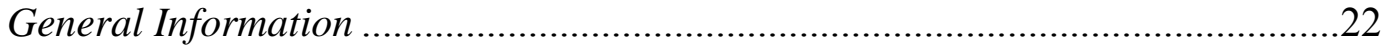

Quality Assurance program Participation........................................................24

Knowledge of Management Practices .............................................................2

Participation in D/BQA Programs ................................................................

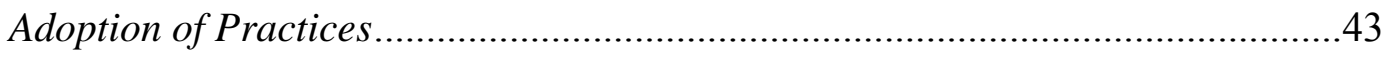

Evaluation of D/BQA Presentation Methods ......................................................47

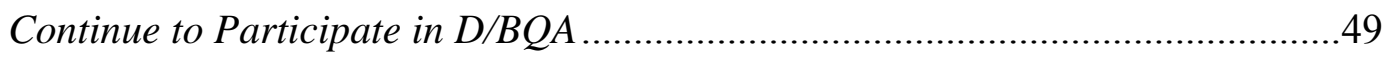

Qualitative Response to Why Producers Would Not Participate ..........................49

Comparison of Levels of Knowledge and Quality Assurance Practices.................52

Knowledge of Data Retention/Recordkeeping .............................................52

Knowledge of Administration of Health Products......................................52

Knowledge of Antibiotic Residue Avoidance …………………………......54

Knowledge of Best Management Practices.................................................54 
Importance of Recording Identification of Animal

Importance of Including Date of Treatment in Records ............................55

Importance of Recording Name of Product Used ......................................58

Importance of Recording the Dosage ......................................................58

Importance of Recording Route of Administration .....................................58

Importance of Including the Withdrawal Time ..........................................59

Importance of Recording the Reason for Treatment..................................59

Prevention of Injection Site Lesions ........................................................6

Proper Administration of Medications ....................................................60

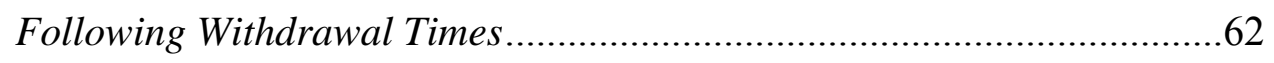

Training Farm Personnel in Cattle Behavior and Handling Techniques..62

Handling Animals to Minimize Stress ........................................................62

Handling Animals to Minimize Injury .....................................................63

Handling Animals to Minimize Bruising .................................................63

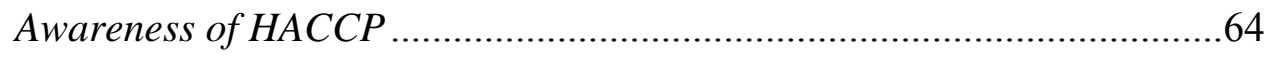

Identify Treated Animals .......................................................................65

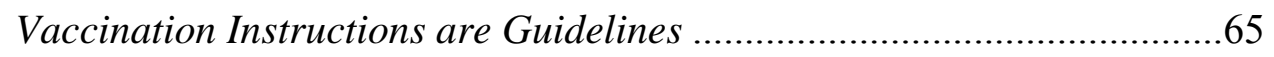

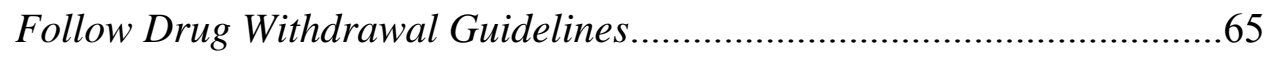

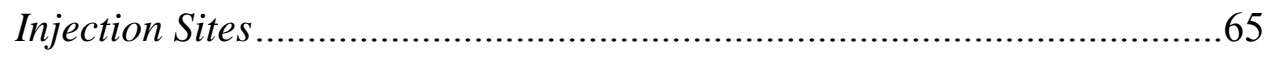

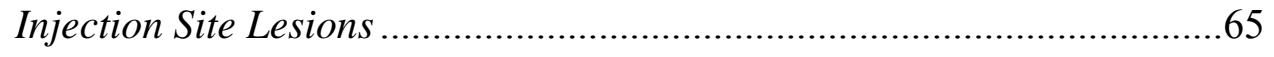

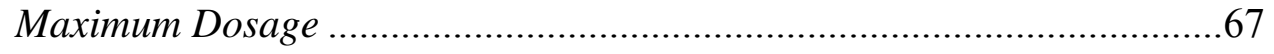

Closeness of Intramuscular Injections......................................................6

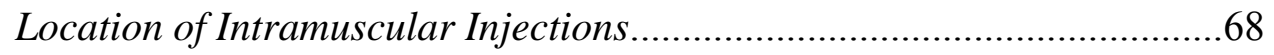


CHAPTER V: Summary, Conclusions, and Recommendations .......................................70

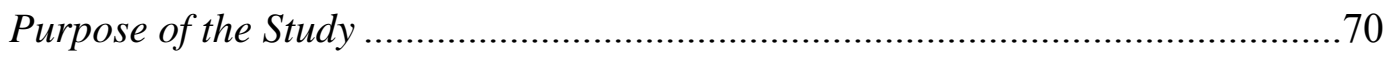

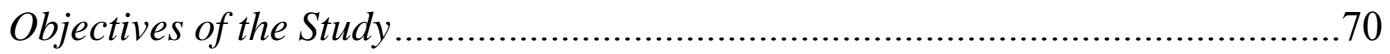

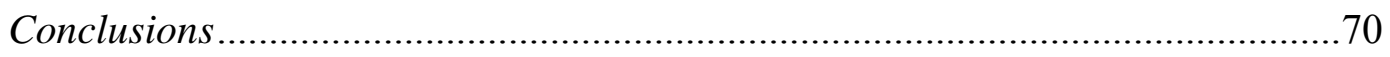

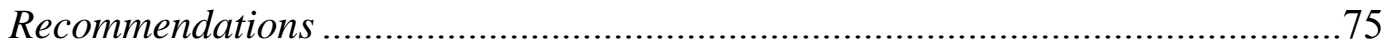

Suggestions for Further Research ..................................................................76

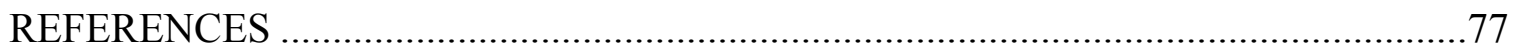

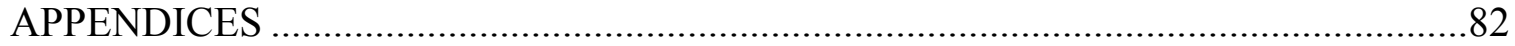

APPENDIX A: First Mailing Survey Cover Letter .............................................83

APPENDIX B: Secondary Mailing Survey Cover Letter.......................................85

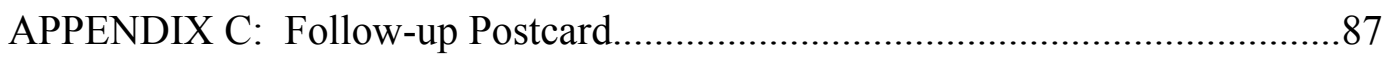

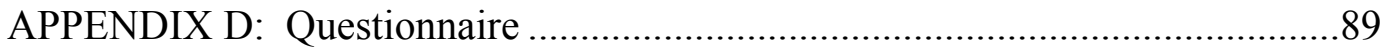

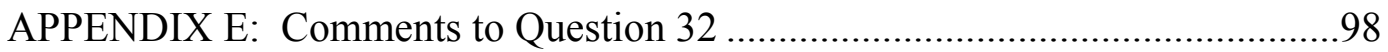

APPENDIX F: Comments to Question 33....................................................102

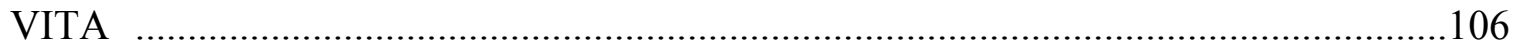




\section{LIST OF TABLES}

Table Title Page

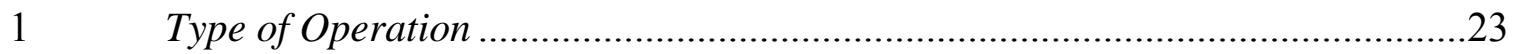

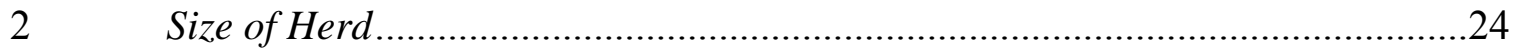

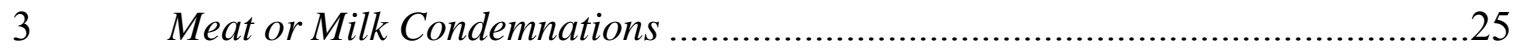

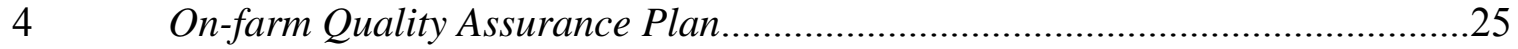

$5 \quad$ Involvement and Types of Milk or Meat Marketing Program ..........................26

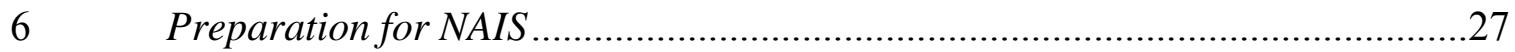

$7 \quad$ Level of Knowledge of Management Practices.............................................28

$8 \quad$ Importance of Topics to Farming Operation......................................................

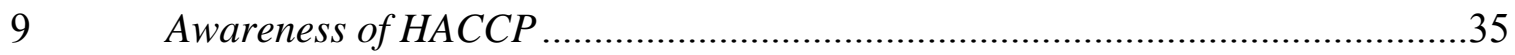

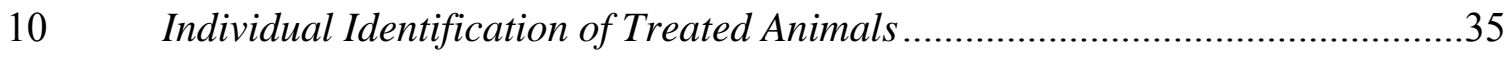

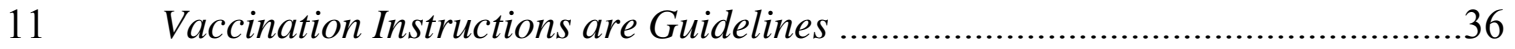

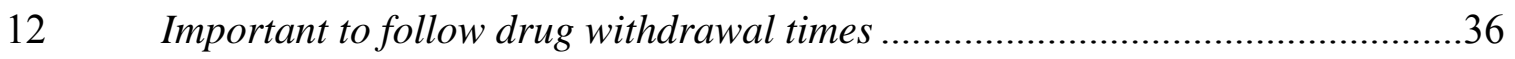

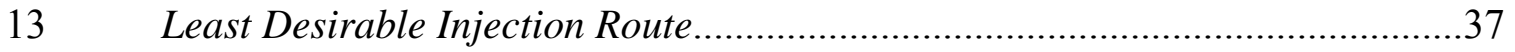

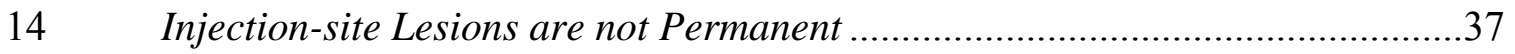

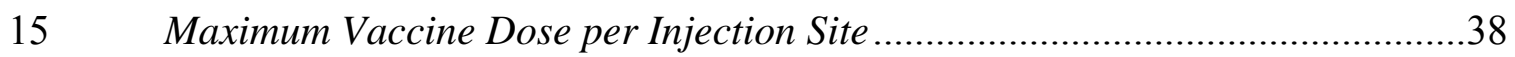

$16 \quad$ IM Injection Site Distance Apart and Location .............................................39

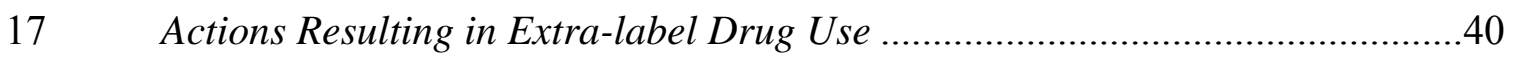

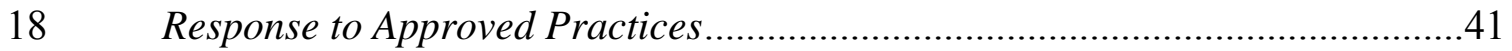

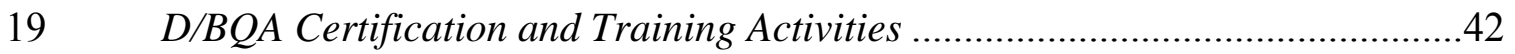

20 On-farm Quality Assurance Plan Prior to Certification ..................................42

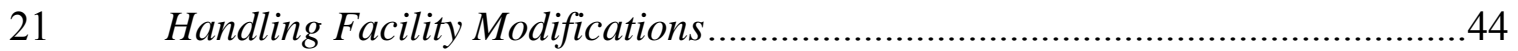


22 Animal Handling Modifications.............................................................. 45

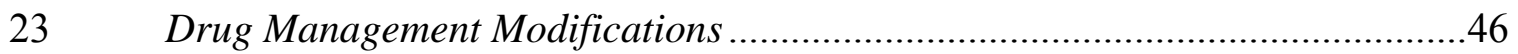

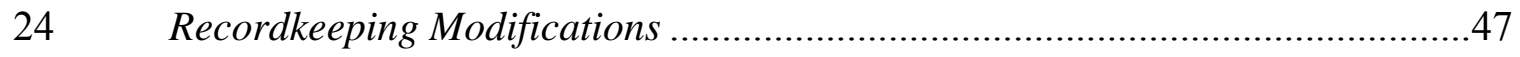

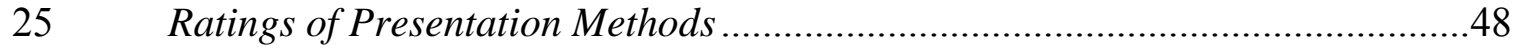

$26 \quad$ Market Advantages to Certification ................................................................49

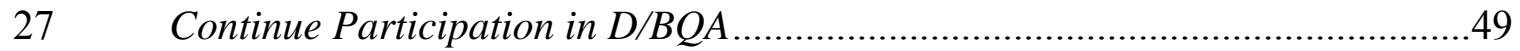

28 Comparison of D/BQA Certification and Level of Knowledge of Issues............53

29 Comparison of D/BQA Certification and Recordkeeping Issues.......................56

30 Comparison of D/BQA Certification and Best Management Practices..............61

31 Comparison of D/BQA Certification and Animal Handling Practices...............64

32 Comparison of D/BQA Certification and Training Content.............................66 


\section{CHAPTER I}

Introduction

The quality and safety of food products are important issues to consumers and must be addressed by food production industries (BQA Certification Manual, 2002; Moore \& Kirk, 2003; Noordhuezen \& Metz, 2005; Schroeder \& Mark, 2000; Wood, Holder \& Main, 1998). Failure to meet public demands regarding quality preferences and assure product safety inevitably result in decreased demand for a particular product (Schroeder \& Mark, 2000). This fact is demonstrated by the situation recently encountered by the United States beef industry. Beef demand suffered a dramatic decline every year for 20 consecutive years until 1999 (Schroeder, 2002). Tatum, Smith, and Belk (2000) indicated that there was a 48\% decline in the demand for domestic beef between 1980 and 1997 alone. Prevalent industry issues, such as beef's variable quality and the risk of drug residue and microbiological contamination, served to undermine consumer confidence in beef products and resulted in the alteration of buying practices (Hooker \& Roe, 2002; Schroeder \& Mark, 2000).

Outbreaks of food-borne illness and food safety recalls have a detrimental impact on the public's perception of the industry (Noordhuizen \& Metz, 2005; Schroeder, Marsh \& Mintert, 2000). Acerbating the problem, such incidents often receive a significant amount of coverage by the media and special interest groups (Coleman, 1995; Wood, Holder, \& Main, 1998). The Food Safety and Inspection Service (FSIS) conducted an average of 41 Class I recalls involving meat or poultry products from 1997 to 2000, resulting in the recall of 24 million pounds per year (Ollinger \& Ballenger, 2003). The Centers for Disease Control (CDC) estimate that approximately 76 million illnesses, 
325,000 hospitalizations, and 5,000 deaths occur each year in the U. S. as a result of food-borne diseases (Mead et al., 1999). In comparison to other meats, beef products have a higher incidence of recalls as a result of bacterial contamination (Schroeder \& Mark, 2000). Schroeder (2002) stated that,

based upon considerable research across numerous studies, several key factors that beef consumers want have been identified. In particular, consumers want beef that is: always tender, flavorful, convenient to prepare, consistently of high and predictable quality, healthy and nutritious, ensured safe from bacteria and any other food-borne illness, and competitively priced relative to substitute meats. (p. 2)

In order to provide products possessing the attributes desired by consumers, "quality can no longer be associated with the product alone but should be extended to the production process itself" (Noordhuizen \& Metz, 2005). Management decisions made during the production process often determine the quality of the end product (Hooker \& Roe, 2002; Tatum, Belk, George, \& Smith, 1999). Therefore, the implementation of integrated, proactive quality management programs that extend from the packing plant to the farm may serve to ensure product safety, reduce contamination, and improve quality (Meeker, 1999; Schroeder \& Mark; 2000). Satisfying consumer demands and reaffirming consumer confidence in beef products will sustain demand (Schroeder \& Mark, 2000; Wood, Holder, \& Main, 1998).

A science-based system of food safety controls known as Hazard Analysis Critical Control Points (HACCP) was established on July 25, 1996 (Stefan, 1997). HACCP is defined as "a systematic approach to the identification, evaluation, and control 
of food safety hazards" (National Advisory Committee on Microbiological Criteria for Foods, n.d.). The concept has since spread worldwide and serves as the template for the majority of new food safety initiatives (Noordhuizen \& Metz, 2005; Stefan, 1997). U. S. producers must comply with such initiatives or be able to provide similar assurances in order to remain competitive in international markets (Meeker, 1999; Stefan, 1997; Wood, Holder \& Main, 1998). Food production industries must be aware of the fact that they are "producing food within a chain and competitive global atmosphere rather than feeding animals independently" (Meeker, 1999).

Quality assurance programs based on HACCP principles are also becoming necessary for access to domestic markets. One such program is the Beef Quality Assurance (BQA) program. Initiated in 1985, the program is now offered in 47 states and involves more than $90 \%$ of U.S. beef production (Beef Quality Assurance, n.d.; Nebraska Beef Quality Assurance, n.d.). Several agricultural organizations, such as ConAgra and Nebraska Corn Fed Beef, require producers to be BQA certified in order to conduct business with them (Hall, 2002). Offered through the Cooperative Extension Service of most states, BQA is a voluntary, educational program based on recommended national guidelines and scientific research (BQA Certification Manual, 2002).

The definition and goal of BQA is to ensure that beef and dairy cattle are maintained in a manner, which will result in a safe and wholesome beef product for the consumer. Specifically, BQA is designed to enhance carcass quality by preventing residues, pathogen contamination and carcass defects such as injection-site lesions and bruising. (BQA Certification Manual, 2002, p. 2) 
By providing producers with technology and information, BQA helps to secure the future success of beef products (Meeker, 1999). "Extension should embrace partnerships with livestock industries, particularly efforts to reach producers with technical advances, environmental assurance education, and on-farm food safety efforts" (Meeker, 1999, p. 365). Within the last fifteen years, the incidence of product defects has decreased, while the safety and quality of beef has substantially improved (Hall, 2002). Much of this success is attributed to the national BQA program.

\section{Statement of the Problem}

It is critical that all educational programs be evaluated. The D/BQA program is no exception. Are producers trained by the West Virginia Extension Service more knowledgeable than producers who have not received training? Are producers trained by the West Virginia Extension Service more likely to implement specific quality assurance practices than producers who have not received training? This information is valuable to plan the direction and content of follow-up, as well as, new quality assurance programs. Purpose of this Study

The purpose of this study was to determine the level of knowledge and use of quality assurance practices by dairy and beef producers in West Virginia and to determine if differences in the level of use existed between D/BQA certified producers and non-certified producers.

Objectives of the Study

The primary objectives of this study were to:

1. Determine the level of knowledge of quality assurance practices by dairy and beef producers in West Virginia. 
2. Determine the level of adoption of quality assurance practices by dairy and beef producers in West Virginia.

3. Determine if differences existed between dairy and beef D/BQA certified producers and producers not certified by the program in their level of knowledge of quality assurance practices.

4. Determine if differences existed between dairy and beef D/BQA certified producers and producers not certified by the program in their level of adoption of quality assurance practices.

5. Identify the strengths and weaknesses of DQA and BQA programs.

\section{Limitations of the Study}

This study was limited to West Virginia dairy and/or beef producers who were included on either the WV D/BQA program database, an official list of dairy producers within the state, or were present on the South Branch or Buckhannon stockyard mailing lists. 


\section{CHAPTER II}

Review of Literature

History of the Dairy/Beef Quality Assurance Program

The Dairy/Beef Quality Assurance program (D/BQA) began in 1982 as a collaborative effort between the United States Department of Agriculture Food Safety Inspection Service (USDA-FSIS) and the U.S. beef industry (BQA Certification Manual, 2002). It was originally known as the Pre-harvest Beef Safety Production Program and focused on addressing beef cattle issues. The dairy cattle component was not included until later. After evaluating, analyzing, and adjusting the production practices of three designated feedlots, USDA-FSIS certified those three feedlots as Verified Production Control feedlots in 1985 (BQA Certification Manual, 2002).

The National Cattleman's Beef Association (NCBA) BQA program was designed on the information obtained from the USDA-FSIS initiative. The primary objective of the program was to address the risk of violative residues occurring in food. It has since been modified to include other production and marketing concerns (Beef Quality Assurance, n.d.).

Influence of HACCP

Reformation of federal food safety regulations in 1996 lead to the concept of Hazard Analysis Critical Points (HACCP), a science-based system of food safety controls (Stefan, 1997). HACCP has been endorsed as "an effective and rational means of assuring food safety from harvest to consumption" (National Advisory Committee on Microbiological Criteria for Foods, n.d.). All slaughter and processing plants have been required to develop, adopt, and implement a HACCP plan as of January 27, 1997 (Stefan, 
1997). In order to comply with principle one of their HACCP plans, the plants must conduct a hazard analysis to identify potential hazards to their facility and the entire food production process (National Advisory Committee on Microbiological Criteria for Foods, n.d). One potential hazard that must be considered is the background, condition, and health status of incoming animals (Stefan, 1997). As a result of the initiation of these stricter food safety standards, incoming cattle and their origin are being examined with increased scrutiny. Due to concern over antibiotic residues, numerous packing plants have already began turning away cows coming from dairies with histories of antibiotic residue violations (Moore \& Kirk, 2003).

\section{Carcass Defects}

According to the National Non-Fed (Cull) Beef Quality Audit conducted in 1994, the top ten quality defects found in beef products were due to management practices that could be easily corrected and/or avoided (North Dakota Beef Quality Assurance, n.d.). Conclusions from this study indicated that meat quality defects resulted in a loss of $\$ 70$ per head of cattle to producers. Roeber et al. (2001) suggested that "producers should promote value in cows and bulls by managing to minimize quality defects, monitoring health and condition, and marketing in a timely manner" (p. 658).

One of the most damaging quality defects found in cattle is the presence of injection-site lesions. Although the injection-site lesions are trimmed out, their presence has a detrimental effect on the tenderness of surrounding tissue (Grandin, 1995).

Tenderness is generally decreased almost four inches in all directions surrounding the location of the lesion (University of California, 2003). George et al. (1995) indicated that beef quality and tenderness are compromised because of the inflammatory reaction that 
occurs when injections are administered intramuscularly. The resulting muscle tissue disruption leads to an increase in muscle collagen content. Incidentally, beef tenderness has been identified as the most desired attribute in a steak by $51 \%$ of consumers, with flavor and juiciness following respectively (Huffman et al., 1996). Similar studies have also proven that lesions can persist from many months to several years (University of California, 2003). Some injection-site lesions are so deep or hidden in the muscle that they are not found by the packing plant and sometimes reach consumers (George et al., 1995).

Excessive bruising has been identified as an additional industry problem. Often a result of improper handling, this particular defects costs the beef industry $\$ 22$ million dollars per year (Grandin, 1995). According to the 1994 National Non-fed Beef Quality Audit, major bruises were present on $31 \%$ of slaughtered cows, and excessive bruising was identified as the number one quality defect (Grandin, 1995; North Dakota Beef Quality Assurance, n.d.).

The use of antibiotics as a component of animal husbandry practices serves as a potential health threat to consumers (Wood, Holder \& Main, 1998). Antibacterials are often used in the dairy, beef, and poultry industries for prophylaxis, chemotherapy, and growth promotion (Witte, 1998). The use of antibiotics in the animal production industry exceeds their amount of use in human medical applications and contributes to the growing problem of microbial resistance. The zoonotic pathogens Salmonella and Campylobacter and the commensals Escherichia coli and enterococci are of the greatest concern regarding cross-resistance among animals and humans. 
Accordingly, eating meat that contains antibiotic residues can be detrimental to people who are allergic to certain medications. The University of California (2003) indicated that approximately $10 \%$ of the U.S. population is allergic to penicillin. A majority of the antibiotics used on dairy farms are in the penicillin family. Due to the aforementioned issues, several prominent organizations, such as the World Health Organization (WHO) and the Swann committee, have recommended that the use of antibiotics in food animals be phased out. Sweden prohibited the use of all antimicrobials as growth proponents in 1986 and several types of antimicrobials have been banned in other countries (Witte, 1998).

\section{Importance of Dairy Cattle Component}

Categorized as non-fed beef, dairy cattle constitute a major source of beef and not always in the form of ground beef (Moore \& Kirk, 2003; North Dakota Beef Quality Assurance, n.d.; University of California, 2003). It has been estimated that 33\% of U. S. beef production is from market dairy cows (Rogers et al., 2004). In 1994, 6.4 billion pounds of beef from non-fed cattle was consumed by the U. S. public (North Dakota Beef Quality Assurance, n.d.). The western states alone send approximately 800,000 dairy cows, valued around $\$ 500$ million dollars, to slaughter each year (Moore \& Kirk, 2003). The sale of non-fed cattle (including culled dairy cows) contributes to approximately 15$20 \%$ of a producer's income (Moore \& Kirk, 2003; North Dakota Beef Quality Assurance, n.d.).

Quality defects that occur in beef cattle, such as injection-site lesions and antibiotic residues, pose an even greater threat to the dairy industry. The incidence of injection-site lesions in round muscle has a higher occurrence in dairy cattle with $34.5 \%$ 
of dairy carcasses having at least one lesion. This compares to $20 \%$ in beef cattle carcasses (Rogers et al., 2004). Other studies have estimated that up to $58 \%$ of dairy cattle have injection-site lesions (North Dakota Beef Quality Assurance, n.d.).

Dairy cattle are three times more likely than beef cattle to have residue violations (Rogers et al., 2004). As a result of residue violations, 3,000 tankers of milk are condemned each year in the U.S. (University of California, 2003). Payne, Bruhn, Reed, Scearce, \& O'Donnell (1999) found that within a five year period, $23 \%$ of dairies had milk condemnations because of drug residues, $21 \%$ had carcass condemnations for the same reason, and $71 \%$ had carcass condemnations because of infection or illness. Some states are mandating DQA certification for farms with a history of antibiotic residue violations (Gibbons-Burgener et al., 1999). Findings such as these substantiate the need for DQA as a component of the BQA program.

\section{Research on Quality Assurance Programs}

Peacock (2003) determined that West Virginia BQA certified producers had a higher net income from their farming operation and a larger herd size than non-certified producers. The operations of certified producers also made up a larger percentage of their household income. Producers certified in the program were younger on average but had spent more years farming than non-certified producers, had a higher level of education, and appeared to be more involved with Extension personnel. They were also more likely to be knowledgeable on current issues facing beef producers. Certified producers cited learning new techniques, marketing, and a quality extension program as reasons for participating, while non-certified producers cited time, money, convenience, and lack of BQA program awareness as reasons for not participating. Benefits to 
participating in the program included prices, marketing, improved product and carcass data.

Sischo, Keirnan, Burns, and Byler (1997) evaluated implementation of the Milk and Dairy Beef Quality Assurance Program (MD/BQAP) and found that there were deficiencies in the HACCP component of the program. Producers gained an understanding of the program but were unable to implement a specific plan on their own farms. They were able to identify hazards and knew how to prevent them but did not apply this knowledge to issues present at their own operations. The program alone did not adequately motivate producers to examine and alter their own practices carefully. Lack of adequate treatment records, deficiencies in understanding how to use antibiotics, and poor veterinarian-client relationships were identified as risk factors for antibiotic residue violations. Producers with histories of antibiotic residues were resistant to implementing management changes that would reduce the risk of having an antibiotic residue. Rogers et al. (2004) stated that dairy producers are not likely to implement HACCP testing programs voluntarily. The addition of a risk assessment tool in addition to the generalized approach of the QAP resulted in a 19\% risk decrease and an increase in the likelihood of farms keeping complete, written records.

Coleman (1995) indicated that the Pasteurized Milk Ordinance, a HACCP-type program, has experienced limited success because of similar issues. Producers felt that the protocol was extreme, did not desire additional regulation, and were unaware of any incentives to implementing the program. These findings are consistent with those of Gardner (1997). Only 10\% of the nation's dairy herds were voluntarily participating in 
the 10-point MDBQAP and the benefits of such HACCP programs are not obvious to producers. The program often met with much skepticism.

Gibbons-Burgener, Kaneen, Lloyd, and Erskine (2000) indicated that Michigan Milk and Dairy Beef Quality (MDBQAP) certification alone had little effect on the adoption of specific management practices. They found specific management practices were adopted irrespective of certification. Voluntarily certified farms were three times more likely to use refrigerated drug storage than non-certified farms, while involuntarily certified farms were two and a half times more likely to maintain good written records than non-certified farms. Involuntarily certified farms were also more likely to have used on-farm residue testing. Herd size had a significant association with refrigeration as it would impact the type and quantity of the drugs present on a given farm. These findings indicate that certification alone may not be sufficient to induce adoption of specific practices. Mandatory certification that resulted from residue violations had the most impact on alteration of management practices.

Additionally, Gibbins-Burgener et al. (1999) found that farms that had a violative antibiotic residue violation were more likely to implement practices in order to prevent further residue violations. As a result, the farms that had experienced violative antibiotic residue violations were more likely to keep written identification records of treated cows, records of treatments, and were of the opinion that insufficient record keeping contributed to the risk of having a violative antibiotic residue. Overall, results indicated that MDBQAP certification alone did not significantly reduce the risk of having violative antibiotic residues in milk. 
The use of milk quality teams is an effective means of improving milk quality and encouraging adoption of recommended practices (Rodrigues \& Ruegg, 2005). The most frequent issues cited by participants as goals were general herd performance, procedures for mastitis control, milking performance, and others including general management, hygiene, treatment, dry cow management, and/or teat health. A majority of the herds participating successfully achieved their goals by the conclusion of the program. Lack of time, other farm problems, lack of focus, seasonal influences, and choice of goals were the reasons cited by those who did not successfully achieve their established goals. Other barriers included time, money, and facility restrictions. Teams with herds housed in stallbarns were more likely to adopt goals related to herd performance than those with herds housed in freestalls, while stallbarn herds were half as likely to adopt recommended management practices and less likely to have written protocol at the end of the program than freestall herds. Freestall herds also were more likely to perform microbial analysis of milk obtained from cows having clinical mastitis, performed regularly scheduled milking system analysis, and more frequent training of milking personnel.

Herds that completed the program reported significant reductions in measures of clinical and subclinical mastitis, reduced bacterial counts in bulk milk, and reduced culling of cows due to mastitis, resulting in improved financial performance due to increased milk quality premiums and decreased losses attributable to mastitis. The majority of herds participating reached their set goals and planned to continue meeting with their teams. 


\section{Summary}

Although it has been repeatedly demonstrated that quality assurance programs are needed and possibly may become mandatory in the future, there are still several problems with the idea. Producers must understand how to relate such broad programs to their own specific operations and must be made to realize the benefits of participating in the

programs. Addressing and resolving these issues will increase voluntary participation and adoption of practices. Supplemental material or actions, such as risk assessment tools or milk quality teams, may be necessary in aiding the implementation of quality assurance programs. Certification alone is not always successful. 


\section{CHAPTER III}

\section{Methodology}

Purpose of the Study

The purpose of this study was to determine the level of knowledge and use of quality assurance practices by dairy and beef producers in West Virginia and to determine if differences in the level of use existed between D/BQA certified producers and non-certified producers.

Objectives of the Study

The primary objectives of this study were to:

1. Determine the level of knowledge of quality assurance practices by dairy and beef producers in West Virginia.

2. Determine the level of adoption of quality assurance practices by dairy and beef producers in West Virginia.

3. Determine if differences existed between dairy and beef D/BQA certified producers and producers not certified by the program in their level of knowledge of quality assurance practices.

4. Determine if differences existed between dairy and beef D/BQA certified producers and producers not certified by the program in their level of adoption of quality assurance practices.

5. Identify the strengths and weaknesses of DQA and BQA programs.

\section{Research Design}

A descriptive research design utilizing a mail survey was used to collect data for the study. The use of a survey was appropriate since "surveys can be a powerful and 
useful tool for collecting data on human characteristics, attitudes, thoughts, and behavior" (Doyle, n.d., ๆ 6). In addition, the survey is "a widely used method of research in sociology, business, political science, and government, as well as in education" (Ary, Jacobs, \& Razavieh, 2002, p. 374). Since the purpose of the survey was "to create a statistical description of the study population," descriptive research methods were the most suitable for the research (Fowler, 1998, p. 9). A survey was used to collect the data for this study in order to describe the respondents' knowledge and adoption of quality assurance practices and evaluate the $\mathrm{D} / \mathrm{BQA}$.

\section{Population}

The target population of this study was dairy producers and/or beef producers in West Virginia. The accessible population for this study was dairy producers $(N=125)$ who were identified on a complete list of dairy producers within the state and beef producers $(N=2,720)$ who were identified on either the South Branch or Buckhannon stockyard mailing lists, the D/BQA program database, or the BQA calf pool list. The lists of beef producers were merged together and those certified in the D/BQA program were identified. Certified producers were also identified on the dairy producer list. To ensure that the lists were accurate and avoid frame and selection errors, all duplicate names and non-residents of West Virginia were removed. The Statistical Package for the Social Sciences (SPSS) was used to select an unbiased random sample of the accessible population. Ninety-two dairy producers and 340 beef producers were selected to participate in the research. 


\section{Instrumentation}

The questionnaire consisted of thirty-three questions and was developed using questions similar to those found in the cow-calf checklist section of the BQA certification manual. The questionnaire was comprised of three sections and utilized a combination of multiple response, true/false, Likert, and open-ended items. The first section of the questionnaire asked for information about the farming operation. Respondents were asked to identify whether they were producers of dairy, beef or both and the size of their cow herd. Inquiries were also made as to whether they had carcass or milk condemnations within the last five years and if they had an on-farm quality assurance plan. Questions were also asked to determine if the respondents were involved in a milk or meat marketing program requiring a quality assurance program and to identify what they had done to prepare for the National Animal Identification System.

The second section of the questionnaire addressed knowledge and opinions of quality assurance issues. Level of knowledge regarding data retention/recordkeeping, administration of health products, antibiotic residue avoidance, and best management practices was rated using the following scale: 1- none, 2- some, 3-average, 4- above average, and 5- very knowledgeable. Respondents were also asked to rate the level of importance of different aspects of recordkeeping, prevention of injection-site lesions, proper administration of medications, following withdrawal times, animal handling aspects, and training farm personnel. The rating scale for the importance of these topics was: 1- not important, 2- somewhat important, 3- average importance, 4- above average importance, and 5- very important. Additional questions were presented using multiple response items. Respondents were asked if they were aware of Hazard Analysis Critical 
Control Points, if all treated animals should be individually identifiable, and the maximum vaccine dose that should be given per injection site. The importance of following vaccination instructions and recommended withdrawal times, proper use of intramuscular injections, and the persistence of injection-site lesions were also addressed.

Section three of the questionnaire inquired about quality assurance certification. Respondents who were not certified in the West Virginia Dairy/Beef Quality Assurance (D/BQA) Program were directed to skip to the last question and indicate any questions or comments. Respondents who were certified in the D/BQA program were asked a variety of questions addressing any impact the program may have had relating to modifications of handling facilities, animal handling, drug management, and recordkeeping. They were to indicate what changes had already been completed and what changes were planned. Respondents were also asked to rate their preference of the slide presentation, calf necropsy, and chute-side training presentation methods. The level of effectiveness of the different methods was rated with the following scale: 1- highly in-effective, 2- ineffective, 3- neutral, 4- effective, and 5- highly effective. Questions were also presented regarding market advantages relative to certification and whether the program was something they would continue to participate in.

Validity of the Instrument. The revised instrument was presented to a panel of experts to establish its content and face validity. The panel of experts consisted of faculty members in Agricultural and Environmental Education and Animal and Veterinary Sciences at West Virginia University. Each individual on the panel had extensive teaching and research experience. Extension experience was also represented on the panel. The panel of experts concluded that the instrument had content and face validity. 
Reliability of the Instrument. The final data set from all respondents was used to determine the instrument's reliability. The data consisted of nominal and ordinal measurement scale responses, therefore the Spearman-Brown split half statistic was utilized to establish the reliability of the instrument. Reliability was found to be exemplary with a coefficient of 0.65 (Robinson, Shaver, \& Wrightsman, 1991). The instrument was found to be reliable.

\section{Data Collection Procedures}

Dillman's (2000) tailored design method was followed for data collection procedures with the exception of the pre-card mailing. The complete questionnaire package consisted of a cover letter, the instrument, and a self-addressed stamped return envelope. For the initial mailing, the complete questionnaire package was sent to all respondents randomly selected to participate in the study. The respondents were given a two-week response deadline before a second mailing attempt was made. The second mailing attempt involved sending the complete questionnaire package to all participants who had not responded to the initial mailing. After approximately one month, reminder cards were sent out to the remaining non-respondents and they were given a two-week response deadline.

\section{Analysis of Data}

Each respondent was identified by a numerical code that was placed on the survey that they were to receive. This code was used to follow-up on non-respondents and was later destroyed to protect the anonymity of the respondent. An Excel spreadsheet was used for data entry. Responses to open-ended questions were documented in full text format and coded. 
The collected data were analyzed using the Statistical Package for the Social Sciences (SPSS) 11.0 for Windows. Descriptive analyses appropriate for the respective scale of measurement were performed on the data including measures of central tendency (mean, median, or mode) and variability (frequencies or standard deviation). Appropriate measures of association (Pearson product moment correlation, Phi, Cramers V, Kendall tau B, Kendall tau C) were also used to examine relationships between D/BQA program certification and knowledge and adoption of quality assurance practices. A Chi-square test was used to compare nominal and ordinal level variables.

\section{Use of Findings}

The findings of this study will be used to evaluate the D/BQA program. The program's effectiveness may be demonstrated by the fact that certified producers were more knowledgeable of quality assurance issues and more likely to practice or adopt quality assurance practices than non-certified producers. The results will be used to validate the quality of the D/BQA program and may reveal areas needing improvement. 


\section{CHAPTER IV}

\section{Findings}

\section{Purpose of the Study}

The purpose of this study was to determine the level of knowledge and use of quality assurance practices by dairy and beef producers in West Virginia and to determine if differences existed in the levels of knowledge and use between Dairy/Beef Quality Assurance (D/BQA) certified producers and non-certified producers.

\section{Objectives of the Study}

The primary objectives of this study were to:

1. Determine the level of knowledge of quality assurance practices by dairy and beef producers in West Virginia.

2. Determine the level of adoption of quality assurance practices by dairy and beef producers in West Virginia.

3. Determine if differences existed between dairy and beef D/BQA certified producers and producers not certified by the program in their level of knowledge of quality assurance practices.

4. Determine if differences existed between dairy and beef D/BQA certified producers and producers not certified by the program in their level of adoption of quality assurance practices.

5. Identify the strengths and weaknesses of DQA and BQA training programs.

\section{Findings}

The target population for the study was all dairy and beef producers in West Virginia. The accessible population consisted of 125 dairy producers from throughout 
the state and 2,720 beef producers who sold livestock at the South Branch and Buckhannon markets. A sample of 432 individuals ( 92 dairy producers and 340 beef producers) was randomly selected to participate in the research study using the SPSS statistical package. All 432 producers were sent the initial questionnaire. After the initial mailing, this number was reduced because the addresses were not current for 12 producers, two producers refused to participate in the study, seven producers indicated that they were no longer in the livestock business, and one producer had died. Out of the 410 potential respondents in the random sample, 202 producers responded to the survey for a $49 \%$ response rate. Of the total respondents, 31 were dairy producers, 154 were beef producers, and 13 producers indicated that they were involved in both dairy and beef production.

Of the 202 responses, 106 were received by the initial deadline and were considered early respondents, while 96 were received after the initial deadline and were considered to be late respondents. According to Ary, Jacobs, and Razavieh (2002), late respondents are similar to non-respondents. An independent t-test statistical procedure was used to compare the early and late respondents to determine if significant differences existed in their responses to the knowledge questions on the survey. Significant differences $(\alpha \leq .05)$ were found between the early and late respondents. As a result, generalizations from the findings of this study were limited to the actual respondents who participated in the study.

\section{General Information}

Characteristics of the producers' farming operations were described by the categories of type of operation, herd size, incidence of carcass and/or milk 
condemnations, on-farm quality assurance program, involvement in a milk or meat marketing program, and response to the National Animal Identification System. Thirtyone of the respondents $(15.7 \%)$ indicated that they were involved in a dairy operation. One-hundred and fifty-four of the respondents $(77.8 \%)$ indicated that they were involved in a beef operation. Thirteen of the respondents $(6.6 \%)$ indicated that they were both beef and dairy producers (see Table 1).

Table 1

Type of Operation

\begin{tabular}{lcc}
\hline Categories & $N$ & $\%$ \\
\hline Dairy & 31 & 15.7 \\
Beef & 154 & 77.8 \\
Both & 13 & 6.6 \\
\hline Total & 198 & 100.0 \\
\hline
\end{tabular}

One-hundred and twenty-one respondents $(61.1 \%)$ indicated that they had a herd of less than 50 cows. Sixty-five of the respondents $(32.8 \%)$ indicated that they had between 50 and 150 cows in their herd. Ten respondents $(5.1 \%)$ indicated that they had between 150 and 250 cows, while two respondents (1\%) indicated that they had more than 250 cows in their herd (see Table 2). 
Table 2

Size of Herd

\begin{tabular}{lcc}
\hline & $N$ & $\%$ \\
\hline$<50$ cows & 121 & 61.1 \\
$50-150$ cows & 65 & 32.8 \\
$150-250$ cows & 10 & 5.1 \\
$>250$ cows & 2 & 1.0 \\
\hline Total & 198 & 100 \\
\hline
\end{tabular}

Respondents were asked if they had carcass or milk condemnations within the past five years. Three respondents $(1.5 \%)$ indicated they had at least one carcass condemnation within the last five years, while $188(95.4 \%)$ indicated that they had not experienced a carcass condemnation. Six of the respondents $(3 \%)$ indicated that they were not sure whether or not they had a carcass condemnation. Asked if they had milk condemnations within the last five years, seven of the respondents $(4.2 \%)$ answered yes, while $160(95.8 \%)$ responded no (see Table 3).

\section{Quality Assurance Program Participation}

Respondents were asked if they had an on-farm quality assurance plan. Seventyone respondents (39.2\%) indicated they had an on-farm quality assurance plan while 110 respondents $(60.8 \%)$ indicated they did not have a plan (see Table 4$)$. 
Table 3

Meat or Milk Condemnations

\begin{tabular}{lcc}
\hline & $N$ & $\%$ \\
\hline Meat Condemnation & 3 & 1.5 \\
Yes & 188 & 95.4 \\
No & 6 & 3.0 \\
Not Sure & & \\
Milk Condemnation & 7 & 4.2 \\
Yes & 160 & 95.8 \\
No & & \\
\hline
\end{tabular}

Table 4

On-farm Quality Assurance Plan

\begin{tabular}{lcc}
\hline & $N$ & $\%$ \\
\hline Yes & 71 & 39.2 \\
No & 110 & 60.8 \\
\hline
\end{tabular}

Respondents were asked if they were involved in a milk or meat marketing program requiring a farm quality assurance program. Thirty-six respondents $(19.0 \%)$ indicated that they were involved in a milk or meat marketing program requiring a farm quality assurance program. When asked to identify the marketing programs, seven of the 36 respondents $(23.3 \%)$ identified BQA, 11 respondents $(36.7 \%)$ indicated involvement in one of many area calf pools, five respondents (16.7\%) listed DFA-Cooperative, three 
respondents (10.0\%) named participation in the WV Bull Test, and four respondents $(13.3 \%)$ indicated other programs (see Table 5).

Table 5

Involvement and Types of Milk or Meat Marketing Program

\begin{tabular}{lcc}
\hline \multicolumn{1}{l}{$N$} & $\%$ \\
\hline Involvement in Milk or Meat Marketing Programs & \\
Yes & 30 & 19.0 \\
No & 153 & 81.0 \\
Type of Milk or Meat Marketing Programs & \\
BQA & 7 & 23.3 \\
Calf Pool & 11 & 36.7 \\
DFA-Cooperative & 5 & 16.7 \\
Bull Test & 3 & 10.0 \\
Other & 4 & 13.3 \\
\hline
\end{tabular}

Respondents were asked what steps they had taken to prepare for the National Animal Identification System (NAIS). Eighty-six respondents (63.0\%) had applied for and received their premise identification number. Thirty-six respondents $(17.8 \%)$ planned to apply for their identification number or had already applied but had not yet received it. Nineteen of the respondents $(9.4 \%)$ indicated that they had begun individually identifying their cattle or were already using NAIS ear tags. Eight respondents $(4.0 \%)$ had read literature, attended meetings, or spoke with their local extension agent regarding the program. Eight producers $(4.0 \%)$ indicated changes in recordkeeping (see Table 6). 
Table 6

Preparation for NAIS

\begin{tabular}{lcc}
\hline & $N$ & $\%$ \\
\hline Have Premise ID & 86 & 63.0 \\
Applied for Premise ID & 36 & 17.8 \\
Animal ID-tagging & 19 & 9.4 \\
Education-Information & 8 & 4.0 \\
Recordkeeping & 8 & 4.0 \\
Other & 6 & 3.0 \\
\hline
\end{tabular}

Knowledge of Management Practices

Respondents were asked to rate their level of knowledge of data retention/recordkeeping, administration of health products, antibiotic residue avoidance, and best management practices. The rating scale provided was: 1-none, 2-some, 3average, 4-above average, and 5-very knowledgeable. Regarding data retention/recordkeeping, 14 respondents $(7.5 \%)$ rated their knowledge as none. Thirtyfive producers $(18.8 \%)$ indicated that they had some knowledge of the topic. Seventy respondents $(37.6 \%)$ felt that they had an average level of knowledge of data retention/recordkeeping. Forty-eight respondents producers $(25.8 \%)$ rated their knowledge as above average, while $19(10.2 \%)$ reported being very knowledgeable about the topic (see Table 7).

Eight producers $(4.2 \%)$ reported having no knowledge about the administration of health products. Twenty-eight respondents (14.8\%) felt that they had some knowledge about the topic. Fifty-seven respondents (30.2\%) rated their knowledge as average and 
65 respondents (34.4\%) rated their knowledge as above average. Thirty-one producers (16.4\%) felt that they were very knowledgeable of the subject (see Table 7).

Table 7

Level of Knowledge of Management Practices

\begin{tabular}{|c|c|c|c|c|c|c|c|c|c|c|}
\hline & & 气 & & שี & & 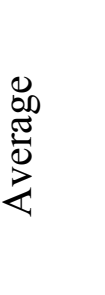 & & 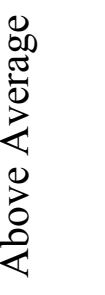 & & 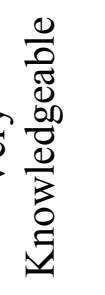 \\
\hline & $N$ & $\%$ & $N$ & $\%$ & $N$ & $\%$ & $N$ & $\%$ & $N$ & $\%$ \\
\hline $\begin{array}{l}\text { Data } \\
\text { retention/recordkeeping }\end{array}$ & 14 & 7.5 & 35 & 18.8 & 70 & 37.6 & 48 & 25.8 & 19 & 10.2 \\
\hline $\begin{array}{l}\text { Administration of health } \\
\text { products }\end{array}$ & 8 & 4.2 & 28 & 14.8 & 57 & 30.2 & 65 & 34.4 & 31 & 16.4 \\
\hline $\begin{array}{l}\text { Antibiotic residue } \\
\text { avoidance }\end{array}$ & 16 & 8.6 & 31 & 16.7 & 44 & 23.7 & 57 & 30.6 & 38 & 20.4 \\
\hline $\begin{array}{l}\text { Best management } \\
\text { practices }\end{array}$ & 7 & 3.7 & 25 & 13.3 & 79 & 42.0 & 54 & 28.7 & 23 & 12.2 \\
\hline
\end{tabular}

Sixteen producers $(8.6 \%)$ reported having no knowledge about the issue of antibiotic residue avoidance. Thirty-one respondents (16.7\%) indicated having some knowledge of the subject, while 44 producers (23.7\%) felt that they had an average level of knowledge. Fifty-seven respondents (30.6\%) reported having an above average level of knowledge, while 38 individuals (20.4\%) felt that they were very knowledgeable of the subject (see Table 7).

When asked about their knowledge of best management practices, seven producers $(3.7 \%)$ felt that they had no knowledge of the subject. Twenty-five 
respondents $(13.3 \%)$ reported having some knowledge of the subject, while $79(42.0 \%)$ rated their knowledge as average. Fifty-four individuals (28.7\%) felt that they had an above average level of knowledge of the subject, and 23 producers $(12.2 \%)$ indicated that they were very knowledgeable about the subject (see Table 7).

Respondents were asked to rate the importance of different aspects of recordkeeping in relation to their farming operation. Eight respondents $(4.1 \%)$ viewed animal identification as an unimportant aspect of recordkeeping, while 90 respondents (46.6\%) felt that it was very important to their operation. Forty-eight (24.9\%) reported it as being of average importance and $36(18.7 \%)$ indicated animal identification as being of above average importance (see Table 8).

Respondents were asked to rate the importance of including the date of treatment as part of general recordkeeping. Including the date of treatment as part of general recordkeeping was very important to 85 producers $(44.5 \%)$. Forty-six producers $(24.1 \%)$ viewed this aspect as being of above average importance, while 42 individuals $(22.0 \%)$ felt that it was of average importance. The information was viewed as being somewhat important by 13 respondents $(6.8 \%)$ and not important by 5 producers $(2.6 \%)$ (see Table 8). 
Table 8

Importance of Topics to Farming Operation

\begin{tabular}{|c|c|c|c|c|c|c|c|c|c|c|}
\hline & \multicolumn{2}{|c|}{$\begin{array}{l}\text { Not } \\
\text { Important }\end{array}$} & \multicolumn{2}{|c|}{$\begin{array}{l}\text { Somewhat } \\
\text { Important }\end{array}$} & \multicolumn{2}{|c|}{$\begin{array}{l}\text { Average } \\
\text { Importance }\end{array}$} & \multicolumn{2}{|c|}{$\begin{array}{l}\text { Above } \\
\text { Average } \\
\text { Importance }\end{array}$} & \multicolumn{2}{|c|}{$\begin{array}{l}\text { Very } \\
\text { Important }\end{array}$} \\
\hline & $N$ & $\%$ & $N$ & $\%$ & $N$ & $\%$ & $N$ & $\%$ & $N$ & $\%$ \\
\hline Recordkeeping & & & & & & & & & & \\
\hline Animal ID & 8 & 4.1 & 11 & 5.7 & 48 & 24.9 & 36 & 18.7 & 90 & 46.6 \\
\hline $\begin{array}{l}\text { Date of } \\
\text { Treatment }\end{array}$ & 5 & 2.6 & 13 & 6.8 & 42 & 22.0 & 46 & 24.1 & 85 & 44.5 \\
\hline Product Used & 4 & 2.1 & 9 & 4.7 & 41 & 21.5 & 61 & 31.9 & 76 & 39.8 \\
\hline Dosage Used & 4 & 2.1 & 7 & 3.7 & 31 & 16.2 & 48 & 25.1 & 101 & 52.9 \\
\hline $\begin{array}{l}\text { Route of } \\
\text { Administration }\end{array}$ & 4 & 2.2 & 8 & 4.3 & 40 & 21.5 & 46 & 24.7 & 88 & 47.3 \\
\hline $\begin{array}{l}\text { Date } \\
\text { Withdrawal } \\
\text { Time is Cleared }\end{array}$ & 6 & 3.2 & 8 & 4.3 & 28 & 15.0 & 42 & 22.5 & 103 & 55.1 \\
\hline $\begin{array}{l}\text { Reason for } \\
\text { Treatment }\end{array}$ & 3 & 1.6 & 4 & 2.2 & 37 & 20.2 & 63 & 34.4 & 76 & 41.5 \\
\hline $\begin{array}{l}\text { Prevention of } \\
\text { Injection-site } \\
\text { lesions }\end{array}$ & 6 & 3.2 & 10 & 5.3 & 39 & 20.9 & 53 & 28.3 & 79 & 42.2 \\
\hline $\begin{array}{l}\text { Proper } \\
\text { Administration } \\
\text { of Medications }\end{array}$ & 1 & .5 & 3 & 1.6 & 21 & 11.2 & 62 & 33.0 & 101 & 53.7 \\
\hline $\begin{array}{l}\text { Following } \\
\text { Withdrawal } \\
\text { Times }\end{array}$ & 4 & 2.2 & 4 & 2.2 & 25 & 13.9 & 42 & 23.3 & 105 & 58.3 \\
\hline $\begin{array}{l}\text { Handling } \\
\text { animals to } \\
\text { minimize stress }\end{array}$ & 2 & 1.0 & 5 & 2.6 & 33 & 17.3 & 56 & 29.3 & 95 & 49.7 \\
\hline
\end{tabular}


Table 8 (continued)

Importance of Topics to Farming Operation

\begin{tabular}{|c|c|c|c|c|c|c|c|c|c|c|}
\hline & \multicolumn{2}{|c|}{$\begin{array}{l}\text { Not } \\
\text { Important }\end{array}$} & \multicolumn{2}{|c|}{$\begin{array}{l}\text { Somewhat } \\
\text { Important }\end{array}$} & \multicolumn{2}{|c|}{$\begin{array}{l}\text { Average } \\
\text { Importance }\end{array}$} & \multicolumn{2}{|c|}{$\begin{array}{l}\text { Above } \\
\text { Average } \\
\text { Importance }\end{array}$} & \multicolumn{2}{|c|}{$\begin{array}{l}\text { Very } \\
\text { Important }\end{array}$} \\
\hline & $N$ & $\%$ & $N$ & $\%$ & $N$ & $\%$ & $N$ & $\%$ & $N$ & $\%$ \\
\hline $\begin{array}{l}\text { Handling to } \\
\text { minimize injury }\end{array}$ & 2 & 1.1 & 2 & 1.1 & 21 & 11.2 & 54 & 28.7 & 109 & 58.0 \\
\hline $\begin{array}{l}\text { Handling to } \\
\text { minimize } \\
\text { bruising }\end{array}$ & 2 & 1.1 & 2 & 1.1 & 28 & 14.9 & 54 & 28.7 & 102 & 54.3 \\
\hline $\begin{array}{l}\text { Training farm } \\
\text { personnel }\end{array}$ & 7 & 3.8 & 5 & 2.7 & 40 & 21.5 & 64 & 34.4 & 70 & 37.6 \\
\hline
\end{tabular}

When asked about the importance of recording information on the product that was used, 76 producers $(39.8 \%)$ indicated that it was very important to their operation. Sixty-one individuals (31.9\%) viewed product information as of above average importance, while 41 respondents $(21.5 \%)$ felt that it was of average importance. Nine respondents (4.7\%) reported it as being somewhat important. Four individuals $(2.1 \%)$ felt that the information was not important (see Table 8).

Respondents were asked to rate the importance of including dosage used in their records. One hundred and one respondents (52.9\%) reported that it was a very important aspect of their recordkeeping. Forty-eight individuals (25.1\%) viewed it as being of above average importance, while 31 producers $(16.2 \%)$ felt that the information was of average importance. Seven $(3.7 \%)$ and 4 respondents $(2.1 \%)$ indicated that it was somewhat important or not important, respectively (see Table 8). 
Respondents were asked the importance of route of administration. Route of administration very important to 88 of the respondents (47.3\%). Forty-six producers (24.7\%) answered that it was of above average importance, while 40 individuals $(21.5 \%)$ felt that recording the information was of average importance. Eight individuals (4.3\%) viewed recording the route of administration as being somewhat important, and four respondents (2.2\%) respondents reported it as being not important (see Table 8 ).

Respondents were asked to rate the importance of recording the date animal will clear the withdrawal period. Recording the date animals will clear the withdrawal period was viewed as being very important by 103 respondents (55.1\%). It was of above average importance to 42 individuals (22.8\%) and of average importance to 28 of the respondents (15.0\%). Eight producers (4.3\%) felt that it was somewhat important to include in their records, while only 6 individuals (3.2\%) felt that the information was not important (see Table 8).

Respondents were asked to rate the importance of recording the reason for treatment or a tentative diagnosis. Recording the reason for treatment or a tentative diagnosis was thought to be very important by 76 respondents (41.5\%). Sixty-three producers (34.4\%) reported it as being of above average importance. Thirty-seven respondents (20.2\%) answered that it was of average importance, while four producers (2.2\%) felt that it was somewhat important. Three respondents (1.6\%) viewed the inclusion of this information as not important (see Table 8).

Producers were asked to report their opinion on the importance of prevention of injection-site lesions. Seventy-nine respondents (42.2\%) felt that it was very important to their operation. Fifty-three individuals (28.3\%) viewed it as above average importance, 
while 39 producers $(20.9 \%)$ answered average importance. Ten of the respondents (5.3\%) thought the issue was somewhat important and six individuals (3.2\%) felt that it was not important (see Table 8).

When asked whether it was important to properly administer medications, 101 (53.7\%) of the respondents answered that it was very important. Sixty-two producers (33.0\%) felt that it was of above average importance. Average importance was reported by 21 individuals (11.2\%), while somewhat important was indicated by three individuals (1.6\%). Properly administering medications was viewed as being not important by one of the respondents $(.5 \%)$ (see Table 8$)$.

Respondents were asked to rate the importance of following withdrawal times for medications. One-hundred and five respondents (58.3\%) thought that it was very important to follow withdrawal times for medications. Above average importance was reported by 42 of the respondents (23.3\%). Twenty-five individuals (13.9\%) indicated average importance, and four producers $(2.2 \%)$ answered somewhat important on the topic. Four respondents (2.2\%) viewed following withdrawal times as being not important (see Table 8).

Respondents were asked to rate the importance of handling animals to minimize stress, injury, and bruising. Handling animals to minimize stress was reported as being very important to 95 respondents (49.7\%). Fifty-six individuals (29.3\%) reported it as being of above average importance, and 33 producers (17.3\%) felt it was of average importance. Five respondents (2.6\%) answered that it was somewhat important, while two individuals (1.0\%) viewed it as being not important. Handling to minimize injury to animals was reported to be very important by 109 respondents $(58.0 \%)$ and above 
average importance to another 54 producers (28.7\%). Average importance was reported by 21 of the respondents (11.2\%), while two individuals (1.1\%) indicated that it was somewhat important. Two producers (1.1\%) felt that handling to minimize injury was not important. Handling animals to minimize bruising was found to be very important to 102 respondents (54.3\%) and of above average importance to another 54 producers (28.7\%). Average importance was reported by 28 respondents (14.9\%) and somewhat important was indicated by two respondents (1.1\%). Two producers $(1.1 \%)$ viewed handling to minimize bruising as not important (see Table 8).

Respondents were asked if training farm personnel in cattle behavior and handling techniques was important. Training farm personnel in cattle behavior and handling techniques was determined to be very important to 70 of the respondents (37.6\%). Sixtyfour respondents (34.4\%) indicated that it was of above average importance, while 40 producers $(21.5 \%)$ rated it as of average importance. Five of the respondents $(2.7 \%)$ reported training farm personnel as being somewhat important, and seven respondents (3.8\%) felt that it was not important (see Table 8).

Respondents were asked if they were aware of Hazard Analysis Critical Control Points (HACCP). Sixty-seven respondents (37.4\%) indicated they were aware of the food industry initiative and 112 individuals (62.6\%) indicated they were unaware of it (see Table 9). 
Table 9

Awareness of HACCP

\begin{tabular}{lcc}
\hline & $N$ & $\%$ \\
\hline Yes & 67 & 37.4 \\
No & 112 & 62.6 \\
\hline
\end{tabular}

Respondents were asked to respond to whether treated animals should be individually identifiable. BQA standards recommend that all treated animals should be individually identified. One-hundred and eighty respondents (94.7\%) felt that treated animals should be individually identifiable, while 10 individuals (5.3\%) did not feel that identifying the treated animals was necessary (see Table 10).

Table 10

Individual Identification of Treated Animals

\begin{tabular}{lcc}
\hline & $N$ & $\%$ \\
\hline Yes & 180 & 94.7 \\
No & 10 & 5.3 \\
\hline
\end{tabular}

Respondents were asked their opinion as to whether vaccination instructions are considered to be guidelines and do not have to be followed. BQA standards recommend that vaccination instructions be followed exactly. One-hundred and ninety respondents $(97.4 \%)$ indicated that vaccination instructions should not be considered as just guidelines. Five respondents $(2.6 \%)$ indicated the instructions were just guidelines and did not have to be followed exactly (see Table 11). 
Table 11

Vaccination Instructions are Guidelines

\begin{tabular}{lcc}
\hline & $N$ & $\%$ \\
\hline True & 5 & 2.6 \\
False & 190 & 97.4 \\
\hline
\end{tabular}

Respondents were asked if they felt that it is important to follow recommended drug withdrawal times. Following recommended drug withdrawal times is crucial in preventing antibiotic residue in beef. One-hundred and eighty-seven respondents (97.4\%) answered yes, that drug withdrawal times were important to follow. Five respondents $(2.6 \%)$ felt that drug withdrawal times were not important to follow (see Table 12).

Table 12

Important to follow drug withdrawal times

\begin{tabular}{lcc}
\hline & $N$ & $\%$ \\
\hline Yes & 187 & 97.4 \\
No & 5 & 2.6 \\
\hline
\end{tabular}

Respondents were asked to indicate the least desirable route to give injections. The choices provided were intramuscular, subcutaneous, or intravenous. Intramuscular injections damage tissue and decrease tenderness and should be avoided if possible. Eighty-six respondents $(48.0 \%)$ reported intramuscular injections as being the least desirable route to give an injection. Thirteen respondents $(7.3 \%)$ chose the subcutaneous 
route, while eighty $(44.7 \%)$ chose the intravenous route as the least desirable (see Table $13)$.

Table 13

Least Desirable Injection Route

\begin{tabular}{lcc}
\hline & $N$ & $\%$ \\
\hline Intramuscular & 86 & 48.0 \\
Subcutaneous & 13 & 7.3 \\
Intravenous & 80 & 44.7 \\
\hline
\end{tabular}

Respondents were asked if injection-site lesions would disappear in a short amount of time. Injection-site lesions are often persistent and do not always disappear. Twenty-one respondents $(11.5 \%)$ indicated that injection-site lesions were not permanent. One-hundred and sixty-one respondents (88.5\%) indicated injection-site lesions were permanent and may not disappear in a short amount of time (see Table 14).

Table 14

Injection-site Lesions are not Permanent

\begin{tabular}{lcc}
\hline & $N$ & $\%$ \\
\hline True & 21 & 11.5 \\
False & 161 & 88.5 \\
\hline
\end{tabular}

Respondents were asked to indicate the maximum vaccine dose that should be given per injection-site. The choices given were $5 \mathrm{cc}, 10 \mathrm{cc}, 15 \mathrm{cc}$, or $20 \mathrm{cc}$. A maximum of $10 \mathrm{cc}$ should be administered per injection site. One hundred and twentysix respondents $(71.2 \%)$ reported $10 \mathrm{cc}$ as the maximum dose per site, while 33 
individuals (18.6\%) chose $5 \mathrm{cc}$. Seven producers (4.0\%) believed $15 \mathrm{cc}$ to be the maximum dose and $20 \mathrm{cc}$ were indicated by 11 of the respondents $(6.2 \%)$ as the maximum dose per injection site (see Table 15).

Table 15

Maximum Vaccine Dose per Injection Site

\begin{tabular}{lcc}
\hline & $N$ & $\%$ \\
\hline $5 \mathrm{cc}$ & 33 & 18.6 \\
$10 \mathrm{cc}$ & 126 & 71.2 \\
$15 \mathrm{cc}$ & 7 & 4.0 \\
$20 \mathrm{cc}$ & 11 & 6.2 \\
\hline
\end{tabular}

Respondents were asked how far apart multiple intramuscular injection sites should be and the location of where such injections should be given. Intramuscular injections should always be administered in the neck and the injection sites should be at least a hands width apart. Thirty-four respondents (19.8\%) preferred to administer IM injections two fingers width apart, while 135 producers (78.5\%) administered injections at least a hands width apart. Three of the respondents (1.7\%) believed that multiple injections could be given at the same site (see Table 16). One hundred and fifty-three respondents (83.6\%) reported that the IM injections should be given in the neck, nine individuals (4.9\%) indicated IM injections should be behind the shoulder, 20 producers $(10.9 \%)$ answered in the top butt, and one individual $(0.5 \%)$ indicated that anywhere is fine to give an IM injection (see Table 16). 
Table 16

IM Injection Site Distance Apart and Location

$N$

Distance Apart

Two fingers width

At least a hands width

Multiple injections can be given at the same location

Location

In the neck

Behind the shoulder

In the top butt

Anywhere is fine
34

135

3

153

9

20

1
1.7

$\%$

19.8

78.5

83.6

4.9

10.9

0.5

Respondents were presented with different scenarios and asked which would be considered an extra-label drug use and require a longer withdrawal time. Exceeding the recommended dosage, use of a different route of administration than listed, and use of medication for a species not listed all constitute extra-label drug use. Twenty of the respondents $(11.7 \%)$ reported that administering more than the recommended dosage would be considered extra-label drug use and two producers $(1.2 \%)$ chose using a medication for species other than the ones listed on the label. One hundred and fortynine respondents $(87.1 \%)$ chose an alternative selection which combined three of the separate choices (administering more than the recommended dosage, using a different route of administration than listed, and use of a medication for species not listed). None 
of the respondents selected the use of a different gauge needle as having an impact on withdrawal time (see Table 17).

Table 17

Actions Resulting in Extra-label Drug Use

\begin{tabular}{lcc}
\hline & $N$ & $\%$ \\
\hline Exceeding recommended dosage & 20 & 11.7 \\
Use of a different route of administration than listed & 0 & 0 \\
Use of a different gauge needle & 0 & 0 \\
Use of medication for a species not listed & 2 & 1.2 \\
$\begin{array}{l}\text { Exceeding recommended dosage, use of different } \\
\text { route of administration, and use of medication for } \\
\text { species not listed are all extra-label drug uses. }\end{array}$ & 149 & 87.1 \\
\hline
\end{tabular}

Respondents were asked to indicate if they have a marketing plan for culling and marketing their cattle, if they regularly consult with their veterinarian about an animal health program, and if they would personally eat the meat from all of their market cows. One hundred and twenty-seven respondents (69.0\%) indicated that they had a marketing plan for their cows. Ninety-nine respondents (52.1\%) regularly consulted with their veterinarian about animal health, and 178 respondents $(91.8 \%)$ would eat the meat from all of their cows (see Table 18). 
Table 18

Response to Approved Practices

\begin{tabular}{lcccc}
\hline & \multicolumn{2}{c}{ Yes } & \multicolumn{2}{c}{ No } \\
\cline { 2 - 5 } & $N$ & $\%$ & $N$ & $\%$ \\
\hline Market Plan for culling and marketing cows & 127 & 69.0 & 57 & 31.0 \\
Consult with Veterinarian about herd health & 99 & 52.1 & 91 & 47.9 \\
Eat Personal Products & 178 & 91.8 & 16 & 8.2 \\
\hline
\end{tabular}

\section{Participation in D/BQA Programs}

Respondents were asked to identify if they were certified in the WV D/BQA program. Out of 183 respondents, 57 (31.1\%) indicated that they were currently certified in the program. One hundred and twenty-six respondents $(68.9 \%)$ were not currently certified in the program. The producers certified in the program were then asked the last time that they had participated in a D/BQA training session. Of the 65 responses to the question, 36 producers $(55.4 \%)$ had participated in a session within the past year.

Eighteen respondents $(27.7 \%)$ had participated in a session one to two years ago, while 11 of the respondents $(16.9 \%)$ had participated in training more than two years ago (see Table 19). 
Table 19

D/BQA Certification and Training Activities

\begin{tabular}{lcc}
\hline & $N$ & $\%$ \\
\hline $\begin{array}{l}\text { D/BQA Certification } \\
\text { Yes }\end{array}$ & 57 & 31.1 \\
No & 126 & 68.9 \\
Last D/BQA Training & & \\
Less than one year ago & 36 & 55.4 \\
1-2 years ago & 18 & 27.7 \\
More than 2 years ago & 11 & 16.9 \\
\hline
\end{tabular}

Respondents were asked if they had an on-farm quality assurance program before becoming certified. Twenty-three respondents (35.9\%) of the 64 respondents indicated that they had an on-farm program before becoming certified (see Table 20).

Table 20

On-farm Quality Assurance Plan Prior to Certification

\begin{tabular}{lcc}
\hline & $N$ & $\%$ \\
\hline Yes & 23 & 35.9 \\
No & 41 & 64.1 \\
\hline
\end{tabular}

Respondents were asked a series of open-ended questions about changes completed and changes planned in their farming operations as a result of D/BQA training. The information presented in the following section (Tables 21-24) is a compilation of the 
producers' responses to these open-ended questions. Qualitative data analysis techniques were utilized.

Adoption of Practices

Respondents were asked if they had planned or made any changes to their handling facilities, animal handling practices, drug management practices, or recordkeeping practices as a result of the $\mathrm{D} / \mathrm{BQA}$ training. Twenty-two of the respondents (34.9\%) indicated that they had made changes and seven respondents (11.1) reported plans to change their handling facilities. Thirteen of the 29 respondents $(44.8 \%)$ made changes to the headgate or chute that they used. Three of the 29 respondents (10.3\%) made changes involving tubs or alleyways, while seven respondents $(24.1 \%)$ had altered their holding or sorting pens. Six of the 29 producers (20.7\%) planned to modify their headgate or chute systems, two producers $(6.9 \%)$ planned to change tubs or alleyways, and two respondents (6.9\%) anticipated changes to their holding or sorting pens (see Table 21). 
Table 21

Handling Facility Modifications

\begin{tabular}{lcc}
\hline & $N$ & $\%$ \\
\hline Handling facility changes & 22 & 34.9 \\
Changes Planned in 12 Months & 7 & 11.1 \\
No Changes & 34 & 54.0
\end{tabular}

Changes completed ${ }^{1}$

Headgate/chute

Tub/alleyway

3

10.3

Holding/sorting pen

Other

Changes planned ${ }^{1}$

Headgate/chute

Tub/alleyway

Holding/sorting pen

2

6.9

Other

8

27.6

\footnotetext{
${ }^{1}$ Percentages were based on total number of individuals who reported completing and/or planning changes.
}

Twenty-seven respondents $(47.4 \%)$ had made changes involving their animal handling practices. Eight of the 27 respondents (29.6\%) had made changes regarding injection-sites of vaccines, five producers $(18.5 \%)$ had taken steps to reduce stress on the animals, and nine individuals $(33.3 \%)$ reported management changes related to animal handling. Changes planned in the next twelve months included injection sites $(n=2$, $7.4 \%)$, stress reduction $(n=2,7.4 \%)$, and management $(n=1,3.7 \%)$ (see Table 22$)$. 
Table 22

Animal Handling Modifications

\begin{tabular}{lcc}
\hline & $N$ & $\%$ \\
\hline Changes in Animal Handling Practices & 27 & 47.4 \\
No Changes in Animal Handling Practices & 30 & 52.6
\end{tabular}

Changes Completed $^{1}$

Injection sites

8

29.6

Reduce stress

5

18.5

Management

9

33.3

Other

Changes Planned ${ }^{1}$

Injection sites

2

7.4

Reduce stress

2

7.4

Management

1

3.7

Other 1

3.7

${ }^{1}$ Percentages were based on total number of individuals who reported completing and/or planning changes.

Thirty-one respondents $(50.0 \%)$ reported changes in their drug management practices. Changes made involved recordkeeping $(n=5,15.6 \%)$, management $(n=17$, $53.1 \%)$, injection-site $(n=10,31.3 \%)$, and supplies $(n=2,6.3 \%)$. Changes planned in the next twelve months included recordkeeping $(n=1,3.1 \%)$, management $(n=1,3.1 \%)$, and supplies $(n=1,3.1 \%)$ (see Table 23$)$. 
Table 23

Drug Management Modifications

\begin{tabular}{lcc}
\hline & $N$ & $\%$ \\
\hline Changes in Drug Management & 31 & 50.0 \\
Drug Management Changes Planned & 1 & 1.6 \\
No Changes in Drug Management & 30 & 48.4
\end{tabular}

Changes Completed ${ }^{1}$

$\begin{array}{lcc}\text { Recordkeeping } & 5 & 15.6 \\ \text { Management } & 17 & 53.1 \\ \text { Injection-site } & 10 & 31.3 \\ \text { Supplies } & 2 & 6.3 \\ \text { anges Planned }^{1} & 1 & 3.1 \\ \text { Recordkeeping }^{\text {Management }} & 1 & 3.1 \\ \text { Supplies }^{\text {Sula }} & 1 & 3.1\end{array}$

${ }^{1}$ Percentages were based on total number of individuals who reported completing and/or planning changes.

Changes in recordkeeping practices were reported by $30(48.4 \%)$ of the respondents. Nine of the 30 respondents $(30.0 \%)$ indicated changes involving animal identification or tracking, four individuals (13.3\%) reported the use of computers, and twelve respondents $(40.0 \%)$ answered increased recording of treatment/vaccine information. Changes planned in the next twelve months included the use of computer ( $n$ $=2,6.7 \%)$ and keeping more thorough records $(n=2,6.7 \%)$ (see Table 24$)$. 
Table 24

Recordkeeping Modifications

\begin{tabular}{lcc}
\hline & $N$ & $\%$ \\
\hline Recordkeeping Changes & 30 & 48.4 \\
No Recordkeeping Changes & 32 & 51.6
\end{tabular}

Changes Completed $^{1}$
Animal ID-tracking
9
30.0
Use of computer
4
13.3
Treatment-Vaccine information
12
40.0
Other
6
20.0
Changes Planned ${ }^{1}$
Computer Use
2
6.7
More thorough records
2
6.7

\footnotetext{
${ }^{1}$ Percentages were based on total number of individuals who reported completing and/or planning changes.
}

\section{Evaluation of D/BQA Presentation Methods}

Respondents were asked to rate the different presentation methods utilized by the D/BQA training program. Thirty-four respondents (56.7\%) felt that the slide presentation was effective in getting the information across. Other ratings of the slide presentation were: highly effective $(n=8,13.3 \%)$, neutral $(n=14,23.3 \%)$, in-effective $(n=3,5.0 \%)$ and highly in-effective $(n=1,1.7 \%)$. The calf necropsy was found to be highly effective by 22 respondents $(40.0 \%)$. Effective $(n=21,38.2 \%)$, neutral $(n=11,20.0 \%)$, and highly in-effective $(n=1,1.8 \%)$ ratings were also reported. The chute-side training provided by D/BQA was reported to be highly effective by 32 respondents $(52.5 \%)$. 
Other ratings were: effective $(n=18,29.5 \%)$, neutral $(n=9,14.8 \%)$, and highly ineffective $(n=2,3.3 \%)$ (see Table 25).

Table 25

Ratings of Presentation Methods

\begin{tabular}{lccccccccccc}
\hline & $\begin{array}{l}\text { Highly In- } \\
\text { effective }\end{array}$ & In-effective & Neutral & \multicolumn{2}{c}{ Effective } & \multicolumn{2}{l}{$\begin{array}{l}\text { Highly } \\
\text { effective }\end{array}$} \\
& $N$ & $\%$ & $N$ & $\%$ & $N$ & $\%$ & $N$ & $\%$ & $N$ & $\%$ \\
\hline $\begin{array}{l}\text { Slide } \\
\text { Presentation }\end{array}$ & 1 & 1.7 & 3 & 5.0 & 14 & 23.3 & 34 & 56.7 & 8 & 13.3 \\
$\begin{array}{l}\text { Calf } \\
\text { Necropsy }\end{array}$ & 1 & 1.8 & 0 & 0.0 & 11 & 20.0 & 21 & 38.2 & 22 & 40.0 \\
$\begin{array}{l}\text { Chute Side } \\
\text { Training }\end{array}$ & 2 & 3.3 & 0 & 0.0 & 9 & 14.8 & 18 & 29.5 & 32 & 52.5 \\
\hline
\end{tabular}

Respondents were asked if they noticed or foresaw market advantages relative to certification in the D/BQA program. Forty-three of the respondents $(69.4 \%)$ noticed or foresaw market advantages relative to certification in the D/BQA program. However, forty-seven responses were provided identifying market advantages. Of the forty-seven responses, $17(36.2 \%)$ identified better health or quality of animals, 18 (38.3\%) identified better pricing and marketing, and 7 (14.9\%) indicated increased consumer confidence in beef and dairy products as advantages to program certification (see Table 26). 
Table 26

Market Advantages to Certification

\begin{tabular}{lcc}
\hline & $N$ & $\%$ \\
\hline Yes & 43 & 69.4 \\
Better health-quality & 17 & 36.2 \\
Better pricing-marketing & 18 & 38.3 \\
Increased consumer confidence & 7 & 14.9 \\
Other & 5 & 10.6 \\
\hline
\end{tabular}

Continue to Participate in D/BQA

Respondents were asked if they would continue to participate in the D/BQA

program. Sixty respondents $(89.6 \%)$ indicated they would continue to participate in the D/BQA program (see Table 27).

Table 27

Continue Participation in D/BQA

\begin{tabular}{lcc}
\hline & $N$ & $\%$ \\
\hline Yes & 60 & 89.6 \\
No & 7 & 10.4 \\
\hline
\end{tabular}

Qualitative Response to Why Producers Would not Participate

Using an open-ended question, respondents were asked why certified producers would choose not to continue to participate in the program. Three producers $(1.5 \%)$ responded to the question. The responses were:

- I feel like a lot of it is just pushing every producer to use Angus cattle. 
- Don't know enough about it.

- A book is good, experience is better.

Many producers had mixed feelings about the D/BQA program. Criticisms of the program's marketing, availability, and oversight were reflected in the following statements:

- We still have much work on BQA training and we also need to really work the sale side of BQA animals. BQA animals should be at least 50 cents premium over non-BQA.

- D/BQA availability, communication, publication, requirements for participation, etc. are lacking!! No mailings!

- No premium for weaning, vaccinating calves returned to farm from local sales.

- I went to one program-they did not have enough material to give out. I was supposed to have been sent material and over 1 year has passed and still nothing. If that is what the programs are like, it is a waste of my time.

- More local training in beef quality assurance.

- Administration and recordkeeping too time consuming. The average small farmer has little time.

- D/BQA? Who remembers? More info. and more info. Can't keep up.

- I and others from Wayne County went through the classes to get our WV BQA numbers but never received them.

- If we are to have a BQA program, we must have a vet to have the recommended best management practices to meet industry quality challenges. 
Numerous producers viewed the $\mathrm{D} / \mathrm{BQA}$ program as beneficial to the industry. Approval of the program was demonstrated by the following comments:

- BQA should be here to stay. I think the big cattle buyers will demand it. A lot less sickness and loss with these cattle.

- I think that this program and its training should be something that all producers should participate in.

- Keep promoting BQA.

- Very important and effective program for all cattle producers.

- The calves from our calf pool should be acceptable to all world markets.

- With animal id coming soon, BQA procedures and certification will increase dramatically in importance.

Misconceptions about the program were evident in statements such as:

- Get out of the Angus Association hip pocket. Quit ignoring the advantage of hybrid vigor.

- It seems that all the government wants to do is run the small family farm out of business.

- D/BQA program needs to offer more dates instead of only one if you must do each year. Should be at least two years in between requirements. Information was requested on variables to track to determine and compare yearly performance of grazing cattle, the questions included in this survey, and certification class dates. One respondent was adamant on the importance of having large animal veterinarians in each county. Producers expressed concern regarding the National Animal Identification System and felt that their farm ID should not be given to any other agency. 
Comparison of Level of Knowledge and Adoption of Quality Assurance Practices

Knowledge of Data Retention-Recordkeeping. A chi-square test of independence was used to determine if a significant difference existed between D/BQA certified and non-certified producers regarding their level of knowledge and level of adoption of quality assurance practices. Thirteen (10.8\%) non-certified respondents indicated that they had no knowledge of data retention-recordkeeping, while none $(0 \%)$ of those certified indicated having no knowledge on the topic. Some knowledge of data retentionrecordkeeping was reported by four certified respondents (7.3\%) and 30 non-certified respondents (25\%). Sixteen certified respondents (29.1\%) and 49 non-certified respondents $(40.8 \%)$ felt that they had an average level of knowledge of data retentionrecordkeeping. An above average level of knowledge of data retention-recordkeeping was chosen by 25 certified producers (45.5\%) and 20 non-certified producers (16.7\%). Ten certified producers (18.2\%) considered themselves to be very knowledgeable of the topic as compared to $6.7 \%(\mathrm{~N}=8)$ of non-certified producers. Chi-square analysis indicated that there was a significant association $(\alpha \leq .05)$ between data retentionrecordkeeping and D/BQA certification $(\chi=30.48, \mathrm{df}=4)$ (see Table 28).

Knowledge of Administration of Health Products. Eight non-certified (6.7\%) producers had no knowledge of administration of health products. Some knowledge of administration of health products was reported by three certified producers $(5.5 \%)$ and 25 non-certified producers $(20.5 \%)$. Nine certified producers (16.4\%) and 42 non-certified producers (34.4\%) indicated an average level of knowledge of administration of health products. An above average level of knowledge of administration of health products was 
Table 28

Comparison of D/BQA Certification and Level of Knowledge of D/BQA Issues

\begin{tabular}{|c|c|c|c|c|c|}
\hline & & \multicolumn{4}{|c|}{ D/BQA Certification } \\
\hline & & \multicolumn{2}{|c|}{ Yes } & \multicolumn{2}{|c|}{ No } \\
\hline & & $N$ & $\%$ & $N$ & $\%$ \\
\hline \multirow{5}{*}{$\begin{array}{l}\text { Data retention- } \\
\text { recordkeeping }\end{array}$} & None & 0 & 0 & 13 & 10.8 \\
\hline & Some & 4 & 7.3 & 30 & 25.0 \\
\hline & Average & 16 & 29.1 & 49 & 40.8 \\
\hline & Above Average & 25 & 45.5 & 20 & 16.7 \\
\hline & Very Knowledgeable & 10 & 18.2 & 8 & 6.7 \\
\hline \multirow{5}{*}{$\begin{array}{l}\text { Administration of health } \\
\text { products }\end{array}$} & None & 0 & 0 & 8 & 6.6 \\
\hline & Some & 3 & 5.5 & 25 & 20.5 \\
\hline & Average & 9 & 16.4 & 42 & 34.4 \\
\hline & Above Average & 27 & 49.1 & 34 & 27.9 \\
\hline & Very Knowledgeable & 16 & 29.1 & 13 & 10.7 \\
\hline \multirow{5}{*}{$\begin{array}{l}\text { Antibiotic residue } \\
\text { avoidance }\end{array}$} & None & 2 & 3.6 & 14 & 11.7 \\
\hline & Some & 4 & 7.3 & 26 & 21.7 \\
\hline & Average & 8 & 14.5 & 31 & 25.8 \\
\hline & Above Average & 23 & 41.8 & 30 & 25.0 \\
\hline & Very Knowledgeable & 18 & 32.7 & 19 & 15.8 \\
\hline \multirow{5}{*}{$\begin{array}{l}\text { Best management } \\
\text { practices }\end{array}$} & None & 0 & 0 & 7 & 5.9 \\
\hline & Some & 3 & 5.4 & 22 & 18.5 \\
\hline & Average & 18 & 32.1 & 53 & 44.5 \\
\hline & Above Average & 24 & 42.9 & 27 & 22.7 \\
\hline & Very Knowledgeable & 11 & 19.6 & 10 & 8.4 \\
\hline
\end{tabular}


reported by 27 certified producers $(49.1 \%)$ and 34 non-certified producers $(27.9 \%)$.

Sixteen certified producers $(29.1 \%)$ and 13 non-certified producers $(10.7 \%)$ felt that they were very knowledgeable of the topic. Chi-square analysis revealed a significant association $(\alpha \leq .05)$ between level of knowledge of administration of health products and D/BQA certification $(\chi=26.14, \mathrm{df}=4)$ (see Table 28$)$.

Knowledge of Antibiotic Residue Avoidance. Two certified producers (3.6\%) and 14 non-certified producers (11.7\%) indicated having no knowledge of antibiotic residue avoidance. Four certified producers $(7.3 \%)$ and 26 non-certified producers $(21.7 \%)$ had some knowledge on the topic. An average level of knowledge of antibiotic residue avoidance was reported by eight certified producers $(14.5 \%)$ and 31 non-certified producers $(25.8 \%)$. Twenty-three certified producers $(41.8 \%)$ and 30 non-certified producers $(25 \%)$ had an above average level of knowledge of the topic, while 18 certified producers $(32.7 \%)$ and 19 non-certified producers (15.8\%) were very knowledgeable of antibiotic residue avoidance. Chi-square analysis revealed a significant association $(\alpha \leq$ .05) between level of knowledge of antibiotic residue avoidance and D/BQA certification $(\chi=17.99, \mathrm{df}=4)($ see Table 28$)$

Knowledge of Best Management Practices. No knowledge of best management practices was reported by seven non-certified producers $(5.9 \%)$. Three certified producers (5.4\%) and 22 non-certified producers (18.5\%) had some knowledge of the topic. An average level of knowledge of best management practices was indicated by 18 certified producers $(32.1 \%)$ and 53 non-certified producers $(44.5 \%)$. Twenty-four certified producers $(42.9 \%)$ and 27 non-certified producers $(22.7 \%)$ reported having an above average level of knowledge of best management practices. Eleven certified 
producers (19.6\%) and 10 non-certified producers $(8.4 \%)$ considered themselves to be very knowledgeable. Chi-square analysis revealed a significant association $(\alpha \leq .05)$ between level of knowledge of best management practices and D/BQA certification $(\chi=$ 18.66, $\mathrm{df}=4)($ see Table 28).

Importance of Recording the Identification of the Animal. Recording the identification of the animal was unimportant to seven non-certified producers (5.8\%). It was somewhat important to one certified producers $(1.8 \%)$ and 10 non-certified producers $(8.3 \%)$. Average importance was reported by five certified producers $(8.8 \%)$ and 40 non-certified (33.1\%) producers. The information was considered to be of above average importance for nine certified producers $(15.8 \%)$ and 23 non-certified producers (19.0\%). Very important was indicated by 42 certified producers (73.7\%) and 41 noncertified producers (33.9\%). Chi-square analysis revealed a significant association $(\alpha \leq$ .05) between importance of animal ID in recordkeeping and D/BQA certification $(\chi=$ 28.38, $\mathrm{df}=4)($ see Table 29).

Importance of Including Date of Treatment in Records. Including the date of treatment as part of recordkeeping was considered not important by five non-certified producers (4.2\%). Somewhat important was reported by one certified (1.8\%) and 12 noncertified producers $(10.0 \%)$. It was considered to be of average importance to six certified (10.5\%) and 33 non-certified producers (27.5\%). Above average importance was indicated by $29.8 \%(\mathrm{~N}=17)$ of certified producers and $21.7 \%(\mathrm{~N}=26)$ of noncertified producers. Date of treatment was found to be very important to $57.9 \%(\mathrm{~N}=33)$ of certified producers and $36.7 \%(\mathrm{~N}=44)$ of non-certified producers. Chi-square analysis 
revealed a significant association $(\alpha \leq .05)$ between recording the date of treatment and D/BQA certification $(\chi=16.07, \mathrm{df}=4)($ see Table 29$)$.

Table 29

Comparison of D/BQA Certification and Recording Issues

\begin{tabular}{|c|c|c|c|c|c|}
\hline \multirow[b]{3}{*}{ Recordkeeping } & & \multicolumn{4}{|c|}{ D/BQA Certification } \\
\hline & & \multicolumn{2}{|c|}{ Yes } & \multicolumn{2}{|c|}{ No } \\
\hline & & $N$ & $\%$ & $N$ & $\%$ \\
\hline \multirow[t]{5}{*}{ Animal ID } & Not Important & 0 & 0 & 7 & 5.8 \\
\hline & Somewhat Important & 1 & 1.8 & 10 & 8.3 \\
\hline & Average Importance & 5 & 8.8 & 40 & 33.1 \\
\hline & Above Average Importance & 9 & 15.8 & 23 & 19.0 \\
\hline & Very Important & 42 & 73.7 & 41 & 33.9 \\
\hline \multirow[t]{5}{*}{ Treatment Date } & Not Important & 0 & 0 & 5 & 4.2 \\
\hline & Somewhat Important & 1 & 1.8 & 12 & 10.0 \\
\hline & Average Importance & 6 & 10.5 & 33 & 27.5 \\
\hline & Above Average Importance & 17 & 29.8 & 26 & 21.7 \\
\hline & Very Important & 33 & 57.9 & 44 & 36.7 \\
\hline \multirow[t]{5}{*}{ Product Used } & Not Important & 0 & 0 & 4 & 3.3 \\
\hline & Somewhat Important & 0 & 0 & 9 & 7.5 \\
\hline & Average Importance & 11 & 19.3 & 28 & 23.3 \\
\hline & Above Average Importance & 20 & 35.1 & 34 & 28.3 \\
\hline & Very Important & 26 & 45.6 & 45 & 37.5 \\
\hline
\end{tabular}


Table 29 (Continued)

Comparison of D/BQA Certification and Recording Issues

\begin{tabular}{|c|c|c|c|c|c|}
\hline & & \multicolumn{4}{|c|}{ D/BQA Certification } \\
\hline & & \multicolumn{2}{|c|}{ Yes } & \multicolumn{2}{|c|}{ No } \\
\hline & & $N$ & $\%$ & $N$ & $\%$ \\
\hline \multirow[t]{5}{*}{ Dosage Used } & Not Important & 0 & 0 & 4 & 3.3 \\
\hline & Somewhat Important & 0 & 0 & 7 & 5.8 \\
\hline & Average Importance & 5 & 8.8 & 24 & 20.0 \\
\hline & Above Average Importance & 16 & 28.1 & 27 & 22.5 \\
\hline & Very Important & 36 & 63.2 & 58 & 48.3 \\
\hline \multirow[t]{5}{*}{ Route of Administration } & Not Important & 0 & 0 & 4 & 3.4 \\
\hline & Somewhat Important & 0 & 0 & 8 & 6.8 \\
\hline & Average Importance & 6 & 10.5 & 32 & 27.4 \\
\hline & Above Average Importance & 12 & 21.1 & 31 & 26.5 \\
\hline & Very Important & 39 & 68.4 & 42 & 35.9 \\
\hline \multirow{5}{*}{$\begin{array}{l}\text { Date Withdrawal Period } \\
\text { cleared }\end{array}$} & Not Important & 0 & 0 & 6 & 5.1 \\
\hline & Somewhat Important & 0 & 0 & 7 & 5.9 \\
\hline & Average Importance & 4 & 7.0 & 22 & 18.6 \\
\hline & Above Average Importance & 11 & 19.3 & 30 & 25.4 \\
\hline & Very Important & 42 & 73.7 & 53 & 44.9 \\
\hline \multirow[t]{5}{*}{ Reason for Treatment } & Not Important & 0 & 0 & 3 & 2.6 \\
\hline & Somewhat Important & 0 & 0 & 4 & 3.4 \\
\hline & Average Importance & 8 & 14.3 & 26 & 22.4 \\
\hline & Above Average Importance & 18 & 32.1 & 41 & 35.3 \\
\hline & Very Important & 30 & 53.6 & 42 & 36.2 \\
\hline
\end{tabular}


Importance of Recording the Name of the Product Used. Recording the name of the product used was considered to be unimportant to $3.3 \%(\mathrm{~N}=4)$ and somewhat important to $7.5 \%(\mathrm{~N}=9)$ of non-certified producers. It was of average importance to $19.3 \%(\mathrm{~N}=11)$ of certified producers and $23.3 \%(\mathrm{~N}=28)$ of non-certified producers. Above average importance was reported by 20 certified producers (35.1\%) and 34 noncertified producers $(28.3 \%)$. Recording the name of the product used was very important to 26 certified producers (45.6\%) and 45 non-certified producers (37.5\%). Chi-square analysis revealed no significant association $(\alpha \geq .05)$ between recording the name of product used and D/BQA certification $(\chi=7.67, \mathrm{df}=4)$ (see Table 29).

Importance of Recording the Dosage. Recording the dosage used was unimportant to $3.3 \%(\mathrm{~N}=4)$ and somewhat important to $5.8 \%(\mathrm{~N}=7)$ of non-certified producers. It was of average importance to $8.8 \%$ of certified producers $(\mathrm{N}=5)$ and $20 \%$ of non-certified producers $(\mathrm{N}=24)$. Sixteen certified producers $(28.1 \%)$ and 27 noncertified producers $(22.5 \%)$ viewed recording the dosage used as being of above average importance. Thirty-six certified producers $(63.2 \%)$ and 58 non-certified producers (48.3\%) saw it as being very important. Chi-square analysis revealed a significant association $(\alpha \leq .05)$ between recording the dosage used and D/BQA certification $(\chi=$ $10.29, \mathrm{df}=4)($ see Table 29).

Importance of Recording the Route of Administration. Recording the route of administration was unimportant to $3.4 \%$ of non-certified producers $(\mathrm{N}=4)$. Somewhat important was reported by $6.8 \%$ of non-certified producers $(\mathrm{N}=8)$. It was of average importance to six certified producers (10.5\%) and 32 non-certified producers (27.4\%). Above average importance was indicated by 12 certified (21.1\%) and 31 non-certified 
(26.5\%) producers. Recording the information was very important to $68.4 \%$ of certified $(\mathrm{N}=39)$ and $35.9 \%$ of non-certified $(\mathrm{N}=42)$ producers. Chi-square analysis revealed a significant association $(\alpha \leq .05)$ between recording the route of administration and D/BQA certification $(\chi=19.98, \mathrm{df}=4)($ see Table 29$)$.

Importance of Including the Withdrawal Time. Including the date that withdrawal time will be cleared as part of records was seen as unimportant by $5.1 \%$ of non-certified producers $(\mathrm{N}=6)$ and somewhat important by $5.9 \%(\mathrm{~N}=7)$. It was of average importance to $7.0 \%$ of certified producers $(\mathrm{N}=4)$ and $18.6 \%$ of non-certified producers $(\mathrm{N}=22)$. Eleven certified producers $(19.3 \%)$ and 30 non-certified producers $(\mathrm{N}=$ 25.4\%) viewed the information as of above average importance. Forty-two certified producers $(\mathrm{N}=73.7 \%)$ and 53 non-certified producers $(44.9 \%)$ felt that it was very important. Ch-square analysis revealed no significant association $(\alpha \leq .05)$ between recording the date withdrawal time will be cleared and D/BQA certification $(\chi=16.25$, df =4) (see Table 29).

Importance of Recording the Reason for the Treatment. Recording the reason for treatment was viewed as unimportant by $2.6 \%(\mathrm{~N}=3)$ of non-certified producers. Somewhat important was reported by $3.4 \%(\mathrm{~N}=4)$ of non-certified producers. Average importance was indicated by $14.3 \%$ of certified producers $(\mathrm{N}=8)$ and $22.4 \%$ of noncertified producers $(\mathrm{N}=26)$. The information was thought to be of above average importance to $32.1 \%$ of certified producers $(\mathrm{N}=18)$ and $35.3 \%$ of non-certified producers $(\mathrm{N}=41)$. Very important was indicated by $53.6 \%$ of certified $(\mathrm{N}=30)$ and $36.2 \%$ of non-certified $(\mathrm{N}=42)$ producers. Chi-square analysis revealed no significant 
difference $(\alpha \leq .05)$ between recording the reason for treatment and D/BQA certification (see Table 29).

Prevention of Injection-Site Lesions. Prevention of injection-site lesions was considered unimportant by $5.1 \%(\mathrm{~N}=6)$ of non-certified producers. The topic was somewhat important to $1.8 \%(\mathrm{~N}=1)$ certified and $7.6 \%(\mathrm{~N}=9)$ non-certified producers. Average importance was reported by $8.8 \%(\mathrm{~N}=5)$ certified and $28 \%(\mathrm{~N}=33)$ noncertified producers. Above average importance was indicated by $26.3 \%(\mathrm{~N}=15)$ certified and $27.1 \%(\mathrm{~N}=32)$ non-certified producers. Thirty-six certified producers $(63.2 \%)$ and $38(32.2 \%)$ non-certified producers felt preventing injection-site lesions was very important. Chi-square analysis revealed a significant association $(\alpha \leq .05)$ between prevention of injection-site lesions and D/BQA certification $(\chi=20.46, \mathrm{df}=4)($ see Table $30)$.

Proper Administration of Medications. Proper administration of medications was thought to be unimportant by 1 non-certified producer $(0.9 \%)$. Three $(2.6 \%)$ found it to be somewhat important. Average importance was reported by 2 certified producers (3.5\%) and 19 non-certified producers (16.2\%). Fifteen certified (26.3\%) and 40 noncertified (34.2\%) producers felt that properly administering medications was of above average importance. Very important was indicated by $70.2 \%$ of certified producers $(\mathrm{N}=$ 40 ) and $46.2 \%$ of non-certified producers $(\mathrm{N}=54)$. Chi-square analysis revealed a significant association $(\alpha \leq .05)$ between properly administering medications and D/BQA certification $(\chi=11.94, \mathrm{df}=4)($ see Table 30$)$. 
Table 30

Comparison of D/BQA Certification and Best Management Practices

\begin{tabular}{|c|c|c|c|c|c|}
\hline & & \multicolumn{4}{|c|}{ DBQA Certification } \\
\hline & & \multicolumn{2}{|c|}{ Yes } & \multicolumn{2}{|c|}{ No } \\
\hline & & $N$ & $\%$ & $N$ & $\%$ \\
\hline \multirow{5}{*}{$\begin{array}{l}\text { Prevention of injection- } \\
\text { site lesions }\end{array}$} & Not Important & 0 & 0 & 6 & 5.1 \\
\hline & Somewhat Important & 1 & 1.8 & 9 & 7.6 \\
\hline & Average Importance & 5 & 8.8 & 33 & 28.0 \\
\hline & Above Average Importance & 15 & 26.3 & 32 & 27.1 \\
\hline & Very Important & 36 & 63.2 & 38 & 32.2 \\
\hline \multirow{5}{*}{$\begin{array}{l}\text { Proper administration of } \\
\text { medications }\end{array}$} & Not Important & 0 & 0 & 1 & 0.9 \\
\hline & Somewhat Important & 0 & 0 & 3 & 2.6 \\
\hline & Average Importance & 2 & 3.5 & 19 & 16.2 \\
\hline & Above Average Importance & 15 & 26.3 & 40 & 34.2 \\
\hline & Very Important & 40 & 70.2 & 54 & 46.2 \\
\hline \multirow{5}{*}{$\begin{array}{l}\text { Following withdrawal } \\
\text { times }\end{array}$} & Not Important & 0 & 0 & 3 & 2.7 \\
\hline & Somewhat Important & 0 & 0 & 3 & 2.7 \\
\hline & Average Importance & 4 & 7.1 & 20 & 17.9 \\
\hline & Above Average Importance & 13 & 23.2 & 27 & 24.1 \\
\hline & Very Important & 39 & 69.6 & 59 & 52.7 \\
\hline \multirow[t]{5}{*}{ Training farm personnel } & Not Important & 1 & 1.8 & 6 & 5.2 \\
\hline & Somewhat Important & 0 & 0 & 5 & 4.3 \\
\hline & Average Importance & 5 & 8.8 & 32 & 27.6 \\
\hline & Above Average Importance & 20 & 35.1 & 39 & 33.6 \\
\hline & Very Important & 31 & 54.4 & 34 & 29.3 \\
\hline
\end{tabular}


Following Withdrawal Times. Following withdrawal times was thought to be unimportant by $2.7 \%$ of non-certified producers $(\mathrm{N}=3)$. Three non-certified producers (2.7\%) viewed it as somewhat important. Four certified producers (7.1\%) and 20 noncertified producers (17.9\%) indicated that following withdrawal times was of average importance. Above average importance was reported by $23.2 \%(\mathrm{~N}=13)$ of certified producers and $24.1 \%(\mathrm{~N}=27)$ of non-certified producers. Thirty-nine certified $(\mathrm{N}=$ $69.6 \%)$ and 59 non-certified $(\mathrm{N}=52.7 \%)$ regarded it as very important. Chi-square analysis revealed no significant association between following withdrawal times and D/BQA certification (see Table 30).

Training Farm Personnel in Cattle Behavior and Handling Techniques. Training farm personnel in cattle behavior and handling techniques was viewed as not important by one certified producer (1.8\%) and six non-certified producers (5.2\%). Five noncertified producers (4.3\%) felt that it was somewhat important. Average importance was reported by $8.8 \%(\mathrm{~N}=5)$ of certified producers and $27.6 \%(\mathrm{~N}=32)$ of non-certified producers. Twenty certified producers (35.1\%) and 39 non-certified producers (33.6\%) thought the training was of above average importance. Very Important was indicated by $54.4 \%$ of certified producers $(\mathrm{N}=32)$ and $29.3 \%$ of non-certified producers $(\mathrm{N}=34)$. Chi-square analysis revealed no significant association between training farm personnel in cattle behavior and handling techniques and D/BQA certification (see Table 30).

Handling Animals to Minimize Stress. Handling animals to minimize stress was found to be unimportant by $1.7 \%$ of non-certified producers $(\mathrm{N}=2)$. Somewhat important was reported by $4.2 \%(\mathrm{~N}=5)$ of non-certified producers. Average importance was indicated by $8.8 \%$ certified $(\mathrm{N}=5)$ and $21.7 \%$ non-certified producers $(\mathrm{N}=26)$. 
Eighteen certified producers (31.6\%) and 32 non-certified (26.7\%) felt that it was of above average importance. Handling animals to minimize stress was believed to be very important by $59.6 \%$ of certified producers $(\mathrm{N}=34)$ and $45.8 \%$ of non-certified producers $(\mathrm{N}=55)$. Chi-square analysis revealed found no significant association between handling animals to minimize stress and D/BQA certification (see Table 31).

Handling Animals to Minimize Injury. Handling animals to minimize injury was not considered important to two (1.7\%) non-certified producers. Somewhat important was also reported by two (1.7\%) non-certified producers. Two certified producers $(3.5 \%)$ and 18 non-certified producers $(15.4 \%)$ indicated that handling to minimize injury was of average importance. Above average importance was reported by 17 (29.8\%) certified producers and $32(27.4 \%)$ non-certified producers. Thirty-eight certified producers (66.7\%) and 63 non-certified producers (53.8\%) believed the issue to be very important. Chi-square analysis revealed no significant association between handling animals to minimize injury and D/BQA certification (see Table 31).

Handling Animals to Minimize Bruising. Handling animals to minimize bruising was unimportant to $1.7 \%$ of non-certified producers $(\mathrm{N}=2)$ and somewhat important to $1.7 \%$ of non-certified producers $(\mathrm{N}=2)$. Average importance was reported by $3.5 \%$ of certified producers $(\mathrm{N}=2)$ and $20.3 \%(\mathrm{~N}=24)$ of non-certified producers. Sixteen certified respondents (28.1\%) and 35 non-certified respondents (29.7\%) indicated that handling to minimize bruising was of above average importance. The issue was very important to $68.4 \%(\mathrm{~N}=39)$ of certified producers and $46.6 \%(\mathrm{~N}=55)$ of non-certified producers. Chi-square analysis revealed a significant association $(\alpha \leq .05)$ between 
handling animals to minimize bruising and D/BQA certification $(\chi=12.70, \mathrm{df}=4)$ (see Table 31).

Table 31

Comparison of D/BQA Certification and Animal Handling Practices

\begin{tabular}{|c|c|c|c|c|c|}
\hline \multirow[b]{3}{*}{ Animal Handling } & & \multicolumn{4}{|c|}{ D/BQA Certification } \\
\hline & & \multicolumn{2}{|c|}{ Yes } & \multicolumn{2}{|c|}{ No } \\
\hline & & $N$ & $\%$ & $N$ & $\%$ \\
\hline \multirow[t]{5}{*}{ Minimize Stress } & Not Important & 0 & 0 & 2 & 1.7 \\
\hline & Somewhat Important & 0 & 0 & 5 & 4.2 \\
\hline & Average Importance & 5 & 8.8 & 26 & 21.7 \\
\hline & Above Average Importance & 18 & 31.6 & 32 & 26.7 \\
\hline & Very Important & 34 & 59.6 & 55 & 45.8 \\
\hline \multirow[t]{5}{*}{ Minimize Injury } & Not Important & 0 & 0 & 2 & 1.7 \\
\hline & Somewhat Important & 0 & 0 & 2 & 1.7 \\
\hline & Average Importance & 2 & 3.5 & 18 & 15.4 \\
\hline & Above Average Importance & 17 & 29.8 & 32 & 27.4 \\
\hline & Very Important & 38 & 66.7 & 63 & 53.8 \\
\hline \multirow[t]{5}{*}{ Minimize Bruising } & Not Important & 0 & 0 & 2 & 1.7 \\
\hline & Somewhat Important & 0 & 0 & 2 & 1.7 \\
\hline & Average Importance & 2 & 3.5 & 24 & 20.3 \\
\hline & Above Average Importance & 16 & 28.1 & 35 & 29.7 \\
\hline & Very Important & 39 & 68.4 & 55 & 46.6 \\
\hline
\end{tabular}

Awareness of HACCP. Twenty-four certified producers (47.1\%) and 38 noncertified producers (32.8\%) indicated that they were aware of HACCP. A chi-square 
analysis revealed no significant association between awareness of HACCP and DBQA certification.

Identify Treated Animals. Fifty-six certified producers (98.2\%) and 110 noncertified producers $(92.4 \%)$ thought that treated animals should be individually identifiable. A chi-square analysis revealed no significant association between belief in individually identifying treated animals and D/BQA certification (see Table 32).

Vaccination Instructions are Guidelines. Fifty-six certified producers (98.2\%) and 120 non-certified producers $(96.8 \%)$ did not feel that vaccination instructions are just guidelines and do not need to be followed. A chi-square analysis revealed no significant association between the fact that vaccination instructions are not just guidelines and D/BQA certification.

Follow Drug Withdrawal Guidelines. Fifty-five certified producers (98.2\%) and 118 non-certified producers $(96.7 \%)$ felt that it was important to follow recommended drug withdrawal times. Chi-square analysis revealed no significant association between following recommended drug withdrawal times and D/BQA certification (see Table 32).

Injection Sites. Thirty-two certified producers (58.2\%) and 51 non-certified producers $(45.9 \%)$ chose intramuscular as the least desirable site to give an injection. Twenty certified producers (36.4\%) and 51 non-certified producers $(45.9 \%)$ chose intravenous as the least desirable injection site. Chi-square analysis revealed no significant association between least desirable injection site and D/BQA certification.

Injection-Site Lesions. Fifty-six certified producers (100\%) and 93 non-certified producers $(82.3 \%)$ disagreed with the statement "Injection-site lesions are not permanent; they will disappear in a short amount of time.” Twenty non-certified producers (17.7\%) 
believed the statement to be true. Chi-square analysis revealed a significant association ( $\alpha$ $\leq .05)$ between beliefs regarding injection-site lesion permanence and D/BQA certification $(\chi=11.24, \mathrm{df}=1)$ (see Table 32).

Table 32

Comparison of D/BQA Certification and Training Content

\begin{tabular}{|c|c|c|c|c|c|}
\hline & & \multicolumn{4}{|c|}{ DBQA Certification } \\
\hline & & \multicolumn{2}{|c|}{ Yes } & \multicolumn{2}{|c|}{ No } \\
\hline & & $N$ & $\%$ & $N$ & $\%$ \\
\hline \multirow[t]{2}{*}{ HACCP } & Yes & 24 & 47.1 & 38 & 32.8 \\
\hline & No & 27 & 52.9 & 78 & 67.2 \\
\hline \multirow[t]{2}{*}{ Individual ID } & Yes & 56 & 98.2 & 110 & 92.4 \\
\hline & No & 1 & 1.8 & 9 & 7.6 \\
\hline \multirow{2}{*}{$\begin{array}{l}\text { Vaccine instructions } \\
\text { are just guidelines }\end{array}$} & True & 1 & 1.8 & 4 & 3.2 \\
\hline & False & 56 & 98.2 & 120 & 96.8 \\
\hline \multirow{2}{*}{$\begin{array}{l}\text { Follow drug } \\
\text { withdrawal times }\end{array}$} & Yes & 55 & 98.2 & 118 & 96.7 \\
\hline & No & 1 & 1.8 & 4 & 3.3 \\
\hline \multirow{3}{*}{$\begin{array}{l}\text { Least Desirable } \\
\text { injection site }\end{array}$} & Intramuscular & 32 & 58.2 & 51 & 45.9 \\
\hline & Subcutaneous & 3 & 5.5 & 9 & 8.1 \\
\hline & Intravenous & 20 & 36.4 & 51 & 45.9 \\
\hline \multirow{2}{*}{$\begin{array}{l}\text { Injection site lesions } \\
\text { are not permanent }\end{array}$} & True & 0 & 0 & 20 & 17.7 \\
\hline & False & 56 & 100 & 93 & 82.3 \\
\hline
\end{tabular}


Table 32 (Continued)

Comparison of D/BQA Certification and Training Content

\begin{tabular}{|c|c|c|c|c|c|}
\hline & & \multicolumn{4}{|c|}{ DBQA Certification } \\
\hline & & \multicolumn{2}{|c|}{ Yes } & \multicolumn{2}{|c|}{ No } \\
\hline & & $N$ & $\%$ & $N$ & $\%$ \\
\hline \multirow{4}{*}{$\begin{array}{l}\text { Maximum Vaccine } \\
\text { Dose }\end{array}$} & $5 \mathrm{cc}$ & 3 & 5.5 & 27 & 24.3 \\
\hline & $10 \mathrm{cc}$ & 50 & 90.9 & 70 & 63.1 \\
\hline & $15 \mathrm{cc}$ & 1 & 1.8 & 5 & 4.5 \\
\hline & $20 \mathrm{cc}$ & 1 & 1.8 & 9 & 8.1 \\
\hline \multirow{3}{*}{$\begin{array}{l}\text { IM Injection-site } \\
\text { Distance Apart }\end{array}$} & Two fingers width & 12 & 22.2 & 20 & 18.5 \\
\hline & At least a hands width apart & 42 & 77.8 & 85 & 78.7 \\
\hline & $\begin{array}{l}\text { Multiple injections can be } \\
\text { given at same site }\end{array}$ & 0 & 0 & 3 & 2.8 \\
\hline \multirow{4}{*}{$\begin{array}{l}\text { IM Injection } \\
\text { Location }\end{array}$} & In the neck & 53 & 93.0 & 88 & 77.2 \\
\hline & Behind the shoulder & 3 & 5.3 & 6 & 5.3 \\
\hline & In the top butt & 1 & 1.8 & 19 & 16.7 \\
\hline & Anywhere is fine & 0 & 0 & 1 & 0.9 \\
\hline \multirow[t]{3}{*}{$\begin{array}{l}\text { Extra-label Drug } \\
\text { Use }\end{array}$} & $\begin{array}{l}\text { Administering more than the } \\
\text { recommended dosage }\end{array}$ & 5 & 9.1 & 15 & 13.9 \\
\hline & $\begin{array}{l}\text { Use of medication for a } \\
\text { different species than listed }\end{array}$ & 0 & 0 & 2 & 1.9 \\
\hline & $\mathrm{A}, \mathrm{B}$, and $\mathrm{C}$ & 50 & 90.9 & 91 & 84.3 \\
\hline
\end{tabular}

Maximum Dosage. When asked the maximum vaccine dose given per injection site, $5.5 \%(\mathrm{~N}=3)$ of certified producers and $24.3 \%(\mathrm{~N}=27)$ of non-certified producers indicated 5 cc. Fifty certified producers $(90.9 \%)$ and $70(63.1 \%)$ non-certified chose 10 
$\mathrm{cc}$ as the maximum dose per site. Fifteen $\mathrm{cc}$ was reported by $1.8 \%(\mathrm{~N}=1)$ of certified producers and $4.5 \%(\mathrm{~N}=5)$ of non-certified producers. One certified producer $(1.8 \%)$ and 9 non-certified producers $(8.1 \%)$ selected $20 \mathrm{cc}$. Chi-square analysis revealed a significant association $(\alpha \leq .05)$ between maximum vaccine dose per site and D/BQA certification $(\chi=14.34, \mathrm{df}=3)($ see Table 32$)$.

Closeness of Intramuscular Injections. As to how far apart intramuscular injection sites should be, $22.2 \%(\mathrm{~N}=12)$ of certified producers and $18.5 \%(\mathrm{~N}=20)$ of non-certified producers reported two fingers width. At least a hands width was indicated by $77.8 \%(\mathrm{~N}=42)$ of certified producers and $78.7 \%(\mathrm{~N}=85)$ of non-certified producers. Three non-certified producers (2.8\%) felt that multiple injections could be given at the same time. Chi-square analysis revealed no significant association $(\alpha \geq .05)$ between IM injection site distance apart and D/BQA certification.

Location of Intramuscular Injections. Fifty-three certified producers (93\%) and 88 non-certified producers $(77.2 \%)$ reported that an intramuscular injection should be given in the neck. In the top butt was indicated by $1.8 \%(\mathrm{~N}=1)$ of certified producers and $16.7 \%(\mathrm{~N}=19)$ of non-certified producers. One non-certified producer $(0.9 \%)$ felt that is was fine to give IM injections anywhere on the body. Chi-square analysis revealed a significant association $(\alpha \leq .05)$ between IM injection location and D/BQA certification $(\chi=8.87, \mathrm{df}=3)($ see Table 32).

Extra Label Drug Use. When asked about actions resulting in extra-label drug use, $9.1 \%(\mathrm{~N}=5)$ of certified producers and $13.9 \%(\mathrm{~N}=15)$ of non-certified producers reported administering more than the recommended dosage as an extra-label drug use. Use of medication for a different species than listed was considered to be extra-label use 
by 2 non-certified producers (1.9\%). Fifty certified producers (90.9\%) and 91 noncertified producers $(84.3 \%)$ indicated administering more than the recommended dosage, using a different route of administration than listed, and use of medication for a different species than listed as actions that are considered extra-label drug and my require longer withdrawal times. Chi-square analysis revealed no significant association $(\alpha \geq .05)$ between actions resulting in extra-label drug use and D/BQA certification (see Table 32). 


\section{CHAPTER V}

Summary, Conclusions, and Recommendations

Purpose of the Study

The purpose of this study was to determine the level of knowledge and use of quality assurance practices by dairy and beef producers in West Virginia and to determine if differences in the level of use existed between D/BQA certified producers and non-certified producers.

Objectives of the Study

The primary objectives of this study were to:

1. Determine the level of knowledge of quality assurance practices by dairy and beef producers in West Virginia.

2. Determine the level of adoption of quality assurance practices by dairy and beef producers in West Virginia.

3. Determine if differences existed between dairy and beef D/BQA certified producers and producers not certified by the program in their level of knowledge of quality assurance practices.

4. Determine if differences existed between dairy and beef D/BQA certified producers and producers not certified by the program in their level of adoption of quality assurance practices.

5. Identify the strengths and weaknesses of DQA and BQA programs.

\section{Conclusions}

The majority of West Virginia dairy/beef producers who responded to the survey had a herd size of less than 50 cows. Few had experienced carcass condemnations or milk 
condemnations. Only three producers $(1.5 \%)$ had experienced a carcass condemnation and less than five percent of the dairy producers (4.2\%) had milk condemned. Most of the producers did not have an on-farm quality assurance plan. Only $19 \%$ of the producers were involved with a milk or meat marketing program requiring a farm quality assurance program. Involvement with BQA and/or area calf pools was the most common marketing program reported by producers. Many producers had already applied for and received their National Animal Identification System premise id number.

Producers reported having an average level of knowledge of data retention/recordkeeping, above average level of knowledge about the administration of health products and antibiotic residue avoidance, and average knowledge of best management practices.

Recording animal identification, date of treatment, product information, dosage used, and route of administration was considered very important by the majority of respondents. The date that the animal will have cleared the withdrawal period and the reason for treatment were also considered to be very important details to be included in records. Most of the producers (42.2\%) thought that preventing injection-site lesions was very important, while $53.7 \%$ viewed properly administering medications as very important as well. Following withdrawal times for medications was also found to be very important by the majority of producers $(58.3 \%)$.

Handling animals to minimize stress, injury, and bruising were all considered very important to the respondents, as was training farm personnel in cattle behavior and handling techniques. 
The majority of respondents (62.6\%) were unaware of Hazard Analysis Critical Control Points (HACCP).

Knowledge of quality control issues was demonstrated by the majority of producers $(94.7 \%)$ responding that treated animals should be individually identified, 97.4\% considering vaccine instructions to be more than just guidelines, and $97.4 \%$ indicating that drug withdrawal times are important to follow. Intramuscular injections were found to be the least desired route to give an injection and $88.5 \%$ of the respondents felt that injection-site lesions are permanent and may not disappear in a short amount of time. The producers also indicated that: the maximum vaccine dose that should be given per injection-site is $10 \mathrm{cc}$., and IM injections should be administered in the neck, each site at least a hands width apart. Administering more than the recommended dosage, using a different route of administration than listed, and use of medication for a species not listed were considered extra-label uses by the majority of respondents.

Most of the producers who responded to the survey had a market plan for culling and marketing their cows, regularly consulted with their veterinarian about animal health, and would eat the meat from all of their own cows.

Only $31.1 \%$ of the respondents were currently certified in the D/BQA program. Most (55.4\%) of those certified had participated in a training less than one year ago and did not have an on-farm quality assurance program before becoming certified.

Of those certified in the program, $34.9 \%$ had made handling facility changes since attending D/BQA training. Modifications involving head gate, chutes, and holding/sorting pens were the most reported. The respondents planned to make changes regarding their headgates, chutes, tubs/alleyways, and holding/sorting pens. Changes in 
animal handling practices were reported by $47.4 \%$ of the certified respondents. The most significant changes involved injection-sites of vaccines and management techniques. Management and facility upgrades were reported as changes planned in the next 12 months. Drug management changes were reported by $50.0 \%$ of respondents, with the majority of changes involving management of medications and injection-site specifics. Changes planned in the next 12 months involved management, recordkeeping, and supplies. Recordkeeping changes were reported by $48.4 \%$ of respondents and included animal id/tracking and increased recording of treatment/vaccine information. Changes planned in the next 12 months included additional use of computers.

Ratings of the different presentation methods utilized by the D/BQA program demonstrated that all are effective means of getting information across. Specifically, the slide presentation was found to be effective by $56.7 \%$ of respondents. Both the calf necropsy and chute-side training were found to be highly effective by $40.0 \%$ and $52.5 \%$ of respondents, respectively.

Market advantages relative to D/BQA certification were perceived by $69.4 \%$ of certified respondents. Better health and quality of animals, better pricing and marketing, and increased consumer confidence in products were the primary benefits seen by certified respondents. The majority of respondents (89.6\%) indicated that they would continue to participate in the program.

Significant differences existed between certified and non-certified respondents regarding knowledge of data retention/recordkeeping, administration of health products, antibiotic residue avoidance, and best management practices. D/BQA certified producers rated their level of knowledge of data retention/recordkeeping consistently higher than 
non-certified respondents. Above average and very knowledgeable levels were reported by $45.5 \%$ and $18.2 \%$ of certified producers. Regarding administration of health products, the majority of certified respondents (49.1\%) reported having an above average level of knowledge as compared to an average level knowledge reported by most non-certified respondents (34.4\%). Certified producers reported an above average level of knowledge compared to an average level of knowledge for non-certified producers. The majority of certified producers had an above average level of knowledge of best management practices versus non-certified producers' average level of knowledge.

D/BQA certified producers were also more aware of the importance of including animal id, date of treatment, dosage used, and route of administration as part of their recordkeeping. The importance of preventing injection-site lesions, properly administrating medications, and handling animals to minimize bruising were realized more by certified producers than non-certified.

Certified producers were also more knowledgeable of important industry issues. They were aware of the fact that injection-site lesions often take a long time to disappear and can sometimes remain permanently. Also, the maximum vaccine dose per site (10 cc) and location of intramuscular injections (in the neck) appeared to be more obvious to those certified in the program.

However, non-certified producers were just as knowledgeable as certified producers regarding extra-label drug use, the importance of following drug withdrawal times and individually identifying treated animals. Certification also appeared to not influence opinions on handling animals to minimize stress and injury, training of farm personnel, or awareness of HACCP. Recording the date withdrawal time will have been 
cleared, the reason for treatment and name of product used were also not influenced by certification.

\section{Recommendations}

Although the program is successful in making producers more knowledgeable of and more likely to adopt recommended quality assurance programs, certain issues still need to be addressed. Several statements made in the comments section of the survey indicated that there was a lack of information about the program. Producers were unsure of whether or not they were certified, did not receive program material or numbers, and made numerous requests for additional information. One producer mentioned mailings, which would be a way to get information out about the program and keep producers up to date. An information sheet including general information (contacts, requirements, training dates, etc.) could be developed and distributed to producers.

In order for information to reach the producers who request or need it, an intact and current database of all producers certified in the program must be constructed and maintained. A sign-in sheet could be provided at each meeting and that sheet given to one person who solely manages the database or works closely with others obtaining the information. Intense collaboration of all parties involved with delivering the program would be necessary.

Recruiting large animal veterinarians (in addition to the state veterinarians) to be active in the program and promote its practices to producers would be another route to encourage participation and distribute information. Several respondents to the survey indicated that they relied on their veterinarians for information that the D/BQA program 
also provides. Integration of the two could be very beneficial to the program and producers.

Establishing evaluation procedures is an integral part of the program planning and development process. Intermittent evaluations of the program should be conducted in order to determine the program's status.

Suggestions for Further Research

Further research should be conducted to determine the success and failures of the program. Ideas for enhancing the program should be identified. This could be achieved by:

- Recreating this study in another state and comparing the results.

- Recreating this study to compare beef and dairy producers.

- Conducting a study of similar quality assurance programs such as pork, poultry, eggs, etc.

- Recreating this study using a more expansive and diverse population.

- Producer retention over time should be studied.

- A marketing comparison of D/BQA certified and non-certified producers. 


\section{REFERENCES}

Beef Quality Assurance. (n.d.). Retrieved May 19, 2005, from http://www.bqa.org/

Ary, D., Jacobs, L. C., \& Razavieh, A. (2002). Introduction to research in education. $\left(6^{\text {th }}\right.$ ed.). California: Wadsworth Group.

Coleman, W. (1995). Animal food safety and dairy regulations, now and in the future: from farm to fork, a state perspective. Journal of Dairy Science, 78, 1204-1206.

Dillman, D. (2000). Mail and internet surveys, the tailored design method. (2 ${ }^{\text {nd }}$ ed.). New York: John Wiley \& Sons.

Fowler Jr., F. (1988). Survey research methods. California: Sage Publications.

Gardner, I. A. (1997). Testing to fulfill HACCP (Hazard Analysis Critical Control Points) requirements: principles and examples. Journal of Dairy Science, 80, 3453-3457.

George, M. H., Morgan, J. B., Glock, R. D., Tatum, J. D., Schmidt, G. R., Sofos, J. N., Cowman, G. L., \& Smith, G. C. (1995). Injection-site lesions: incidence, tissue histology, collagen concentration, and muscle tenderness in beef rounds. Journal of Animal Science, 73, 3510-3518.

Grandin, T. (1995). Bruise levels on fed and non-fed cattle. Retrieved on 9/20/05 from http://www.grandin.com/references/LCIbruise.html

Gibbons-Burgener, S. N., Kaneene, J. B., Lloyd, J. W., \& Erskine, R. J. (1999). Evaluation of certification in the Milk and Dairy Beef Quality Assurance Program and associated factors on the risk of having violative antibiotic residues in milk from dairy farms in Michigan. American Journal of Veterinary Medicine, 60, 1312-1316. 
Gibbons-Burgener, S. N., Kaneene, J. B., Lloyd, J. W., \& Erskine, R. J. (2000). Influence of the Milk and Dairy Beef Quality Assurance Program on dairy farm drug management practices. Journal of American Veterinary Medical Association, 216, 1960-1964.

Hall, J. B. (2002). Livestock update: Virginia joins mid-atlantic group certifying producers on beef quality assurance. Retrieved on 5/10/05, from http://www.ext.vt.edu/news/periodicals/livestock/aps-02_12/aps-170.html.

Hooker, N. H., and Roe, B. (2002). Managing cattle for today's cattle market and beyond: cattle marketing and food safety. Retrieved October 1, 2005, from http://ag.arizona.edu/arec/wemc/cattlemarket/CattleMarketing\&Food_Safety.pdf

Huffman, K. L., Miller, M. F., Hoover, L. C., Wu, C. K., Brittin, H. C., and Ramsey, C. B. (1996). Effect of beef tenderness on consumer satisfaction with steaks consumed in the home and restaurant. Journal of Animal Science, 74, 91-97.

Mead, P. S., Slutsker, L., Dietz, V., McCraig, L. F., Bresee, J. S., Shapiro, C., Griffin, P. M., and Tauxe, R. V. (1999). Food-related illness and death in the United States. Emerging Infectious Diseases, 5,607-625.

Meeker, D. L. (1999). What are the livestock industries doing, and what do they need from us? Journal of Animal Science, 77, 361-366.

Mid-Atlantic Beef Quality Assurance. (2002). Mid-Atlantic beef quality assurance program certification manual, 2002 Edition.

Moore, D. and Kirk, J. Dairy Beef: Maximizing Quality \& Profit, Western Dairy News, 3, (2), March 2003. Retrieved 4/10/05 from http://animalscience.tamu.edu/ansc/ publications/dairypubs/westerndairynews/Marc h03.pdf. 
National Advisory Committee on Microbiological Criteria for Food. (n.d.) Retrieved on Oct. 5, 2005, from http://www.fsis.usda.gov/About_FSIS/NACMCF/index.asp. Nebraska Beef Quality Assurance. (n.d.). Retrieved on June 3, 2005, from http://assuringquality.unl.edu/beef.html.

Noordhuezen, J. P. T. M., and Metz, J. H. M. (2005). Quality control on dairy farms with emphasis on public health, food safety, animal health and welfare. Livestock Production Science, 94, 51-59.

North Dakota Beef Quality Assurance. (n.d.). Overview of quality audits. Retrieved July 12, 2005, from http://www.ag.ndsu.nodak.edu/bqa/manual/overview/htm

Ollinger, M. \& Ballenger, N. (2003, April). Weighing incentives for food safety in meat and poultry. Amber Waves. Retrieved 9/7/2005, from http://www.ers.usda.gov/AmberWaves/April03/Features/WeighingIncentives.htm

Payne, M., Bruhn, C. M., Reed, B,. Scearce, A., \& O’Donnell, J. (1999). On-farm quality assurance programs: a survey of producer and industry leader opinions. Journal of Dairy Science, 82, 2224-2230.

Peacock, S. (2003). Factors Influencing Participation in the Beef Quality Assurance Program of the West Virginia Cooperative Extension Service, Master's Thesis, West Virginia University, [On-line Abstract]. Available https://eidr.wvu.edu/eidr/documentdata.eIDR?documentid=3089

Rodrigues, A. C. O., \& Ruegg, P. L. (2005). Actions and outcomes of wisconsin dairy farms completing milk quality teams. Journal of Dairy Science, 88, 2672-2680. 
Rodrigues, A. C. O., Caraviello, D. Z., \& Ruegg, P. L. (2005). Management of Wisconsin dairy herds enrolled in milk quality teams. Journal of Dairy Science, $88,2660-2671$.

Roeber, D. L., Mies, P. D., Smith, C. D., Belk, K. E., Field, T. G., Tatum, J. D., et al. (2001). National market cow and bull beef quality audit-1999: a survey of producer-related defects in market cows and bulls. Journal of Animal Science, 79(3), 658-665.

Rogers, C. A., Fitzgerald, A. C., Carr, M. A., Covey, B. R., Thomas, J. D. \& Looper, M. L. (2004). On-farm management decisions to improve beef quality of market dairy cows. Journal of Dairy Science, 87, 1558-1564.

Schroeder, T. C. (2002). Producing and marketing quality beef in the $21^{\text {st }}$ century. Retrieved September 20, 2005, from http://extension.usu.edu/files/agpubs/fieldproc02.pdf

Schroeder, T. C., and Mark, D. R. (2000). How can the beef industry recapture lost consumer demand? Retrieved September 30, 2005, from http://www.asas.org/JAS/symposia/proceeding/0926.pdf

Schroeder, T. C., Marsh, T. L., and Mintert, J. (2000). Beef demand determinants: a research summary. Retrieved October 12, 2005, from www.agmanager.info/livestock/marketing/bulletins_2/industry/demand/MF2457 pdf

Sischo, W. M., Kiernan, N. E., Burns, C. M., \& Byler, L. I. (1997). Implementing a quality assurance program using a risk assessment tool on dairy operations. Journal of Dairy Science, 80, 777-787. 
Stefan, G. (1997). Food safety issues affecting the dairy beef industry. Journal of Dairy Science, 80, 3458-3462.

Tatum, J. D., Smith, G. C., and Belk, K. E. (2000). New approaches for improving tenderness, quality, and consistency of beef. Retrieved September, 15, 2005, from http://www.asas.org/JAS/symposia/proceedings/0925.pdf

Tatum, J. D., Belk, K. E., George, M. H., and Smith, G. C. (1999). Identification of quality management practices to reduce the incidence of retail beef tenderness problems: development and evaluation of a prototype quality system to produce tender beef. Journal of Animal Science, 77, 2112-2118.

University of California. (2003). DairyBeef: Maximizing Quality and Profit. [CDROM]. Author.

Witte, W. (1998, February 13). Biomedicine: Medical consequences of antibiotic use in agriculture. Science Magazine, 279, 5353, 996-997.

Wood, J. D., Holder, J. S., \& Main, D. C. J. (1998). Quality assurance schemes. Meat Science, 49, S191-S202. 
APPENDICES 
APPENDIX A

First Mailing Survey Cover Letter 
November 2, 2005

«First» «Last»

«Farm»

«Add»

«City», «State» «Zip»

Dear Producer:

Hello, my name is Andrea Flanagan and I am a graduate student in the Davis College of Agriculture, Forestry, and Consumer Science of West Virginia University. The purpose of the study is to determine livestock and dairy producers' level of knowledge on quality assurance issues. The results of the study will be used to prepare a thesis to partially fulfill the requirements for a Master of Science Degree in Agricultural and Environmental Education.

Participation in this research study, while voluntary, will only take approximately ten minutes of your time. You may skip any question you are not comfortable answering. Please be assured that all information will be held as confidential as possible. Survey results will be reported in a summary format and individual responses will not be identifiable. You will notice a code number at the top right of the first page of the survey. This code will be used to identify non-respondents for follow-up and will be destroyed before the data are analyzed.

A postage-paid self-addressed return envelope in provided for your convenience. Please return the completed questionnaire on or before November 16, 2005. Thank you in advance for your participation in this study.

Sincerely,

Andrea L. Flanagan

Graduate Student

Harry N. Boone, Jr., Ph.D.

Assistant Professor
Phillip I. Osborne

Extension Livestock Specialist 
APPENDIX B

Second Mailing Survey Cover Letter 
November 29, 2005

«First» «Last»

«Farm»

«Add»

«City», «State» «Zip»

Dear Producer:

Hello, my name is Andrea Flanagan and I am a graduate student in the Davis College of Agriculture, Forestry, and Consumer Science of West Virginia University. On November 1, 2005 I mailed you a questionnaire concerning your level of knowledge on quality assurance issues. As of today, I have not received your response. If you have already returned the questionnaire, thank you very much for participating in the study. If you have not returned the questionnaire, your response is vital to the success of the study. Will you take a few minutes and give me your opinions on the quality assurance program.

The purpose of the study is to determine livestock and dairy producers' level of knowledge on quality assurance issues. The results of the study will be used to prepare a thesis to partially fulfill the requirements for a Master of Science Degree in Agricultural and Environmental Education.

Participation in this research study, while voluntary, will only take approximately ten minutes of your time. You may skip any question you are not comfortable answering. Please be assured that all information will be held as confidential as possible. Survey results will be reported in a summary format and individual responses will not be identifiable. You will notice a code number at the top right of the first page of the survey. This code will be used to identify non-respondents for follow-up and will be destroyed before the data are analyzed.

A postage-paid self-addressed return envelope is provided for your convenience. Please return the completed questionnaire on or before December 9, 2005. Thank you in advance for your participation in this study.

Sincerely,

Andrea L. Flanagan

Graduate Student

Robert A. Dailey, Ph.D.

Professor
Harry N. Boone, Jr., Ph.D.

Assistant Professor

Phillip I. Osborne, Ph.D.

Extension Livestock Specialist 
APPENDIX C

Follow-Up Postcard 
January 14, 2006

Dear Dairy or Beef Producer:

I am contacting you regarding the Livestock and Dairy Producers' Knowledge of Quality Assurance Issues survey that was recently sent to you. According to my records, I have not yet received your response. The information that you provide in the survey will be used to complete a thesis that is required in order for me to obtain a Master of Science Degree in Agricultural and Environmental Education.

Your participation is vital to the success of this study and would be greatly appreciated. Please take a few moments to complete the survey and return it by January 28,2006 . Thank you for your cooperation.

Sincerely,

Andrea L. Flanagan

WVU Graduate Student 
APPENDIX D

Questionnaire 


\section{Livestock and Dairy Producers' Knowledge of Quality Assurance Issues}

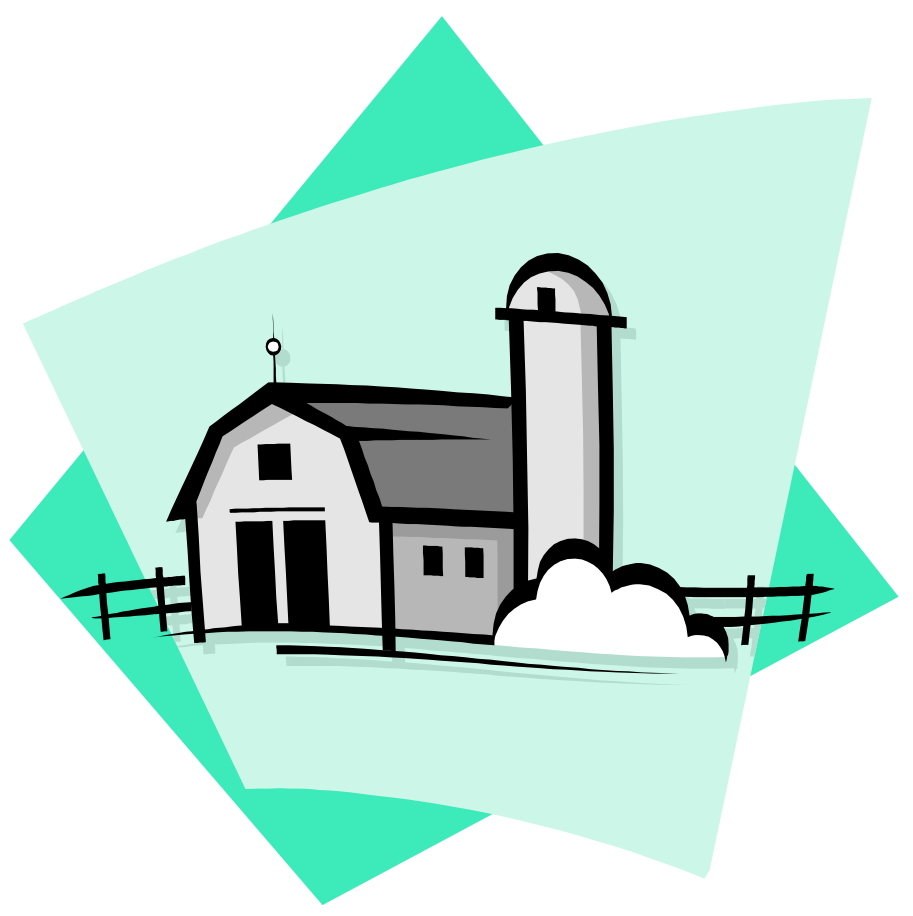

Andrea Flanagan

Graduate Student

Agricultural and Environmental Education

Davis College of Agriculture, Forestry, and Consumer Sciences

West Virginia University

Morgantown, WV 26506 


\section{Livestock and Dairy Producers' Knowledge of Quality Assurance Issues}

The purpose of the study is to determine livestock and dairy producers' level of knowledge on quality assurance issues. Participation in this research study, while voluntary, will only take approximately ten minutes of your time. You may skip any question you are not comfortable answering.

\section{Section I: Demographic Information -- Please check the response(s) that best represents your} answer to the question.

1. What type(s) of operation are you currently involved? (check all that apply):
a. Dairy
b. Beef
c. Both

2. What is the size of your cow herd?
a. Less than 50 cows
b. Between 50 and 150 cows
c. Between 150 and 250 cows
d. More than 250 cows

3. Have you had any carcass condemnations within the last five years due to chemical or microbial contamination?

$\begin{array}{ll}\text { a. } & \text { Yes } \\ \text { b. } & \text { No } \\ \text { c. } & \text { Not Sure }\end{array}$

4. Have you had any milk condemnations within the last five years due to chemical or microbial contamination?
a. Yes
b. No
c. Not Sure

5. Do you have an on-farm quality assurance plan?

a. Yes

b. No 
6. Are you involved in a milk or meat marketing program that requires a farm quality assurance program?

a. Yes

b. No

If so, which one(s):

7. What have you done to prepare for the National Animal Identification System? (ex: apply for premise ID)

\section{Section 2: Quality Assurance Issues}

Instructions: Using the following scale, rate the next series of topics based on your knowledge about each issue: 1 - No Knowledge, 2 - Some knowledge, 3 - Average knowledge, 4 - Above average knowledge, and 5 - Very knowledgeable.

\begin{tabular}{|c|c|c|c|c|c|c|}
\hline \multirow{2}{*}{8.} & \multirow{2}{*}{ Rate your of knowledge of the following topics. } & \multicolumn{5}{|c|}{ Level of Knowledge } \\
\hline & & 芩 & $\begin{array}{l}\text { : } \\
\text { ڤn }\end{array}$ & 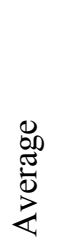 & $\begin{array}{l}0 \\
80 \\
\frac{\pi}{0} \\
2 \\
2 \\
0 \\
0 \\
8 \\
8\end{array}$ & 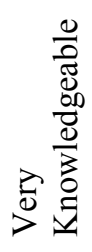 \\
\hline & a. Data retention/recordkeeping & 1 & 2 & 3 & 4 & 5 \\
\hline & b. Administration of health products & 1 & 2 & 3 & 4 & 5 \\
\hline & c. Antibiotic residue avoidance & 1 & 2 & 3 & 4 & 5 \\
\hline & d. Best Management Practices & 1 & 2 & 3 & 4 & 5 \\
\hline
\end{tabular}


Instructions: Using the following scale, rate the next series of topics based on their importance to your farming operation: 1 - Not important, 2 - Some what important, 3 -Average importance, 4 - Above average importance, and 5 - Very important.

\begin{tabular}{|c|c|c|c|c|c|c|c|}
\hline \multirow{2}{*}{9.} & \multirow{2}{*}{\multicolumn{2}{|c|}{$\begin{array}{l}\text { How important are the following to your farming } \\
\text { operation? }\end{array}$}} & \multicolumn{5}{|c|}{ Level of Importance } \\
\hline & & & \multirow[t]{2}{*}{ 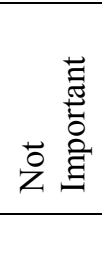 } & \multirow[t]{2}{*}{ 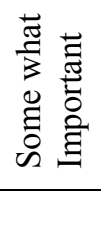 } & \multirow[t]{2}{*}{ 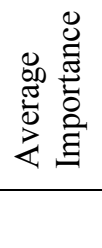 } & \multirow[t]{2}{*}{ 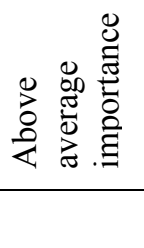 } & \multirow[t]{2}{*}{ 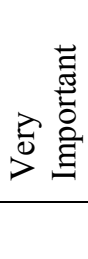 } \\
\hline & a. & Recordkeeping & & & & & \\
\hline & & 1. Animal identification & 1 & 2 & 3 & 4 & 5 \\
\hline & & 2. Date of treatment & 1 & 2 & 3 & 4 & 5 \\
\hline & & 3. Product used & 1 & 2 & 3 & 4 & 5 \\
\hline & & 4. Dosage used & 1 & 2 & 3 & 4 & 5 \\
\hline & & 5. Route of administration & 1 & 2 & 3 & 4 & 5 \\
\hline & & $\begin{array}{l}\text { 6. Date animal will have cleared withdrawal } \\
\text { period }\end{array}$ & 1 & 2 & 3 & 4 & 5 \\
\hline & & 7. Reason for treatment/diagnosis & 1 & 2 & 3 & 4 & 5 \\
\hline & b. & Prevention of injection-site lesions & 1 & 2 & 3 & 4 & 5 \\
\hline & c. & Proper administration of medications & 1 & 2 & 3 & 4 & 5 \\
\hline & d. & Following withdrawal times & 1 & 2 & 3 & 4 & 5 \\
\hline & e. & Handling animals to: & & & & & \\
\hline & & 1. minimize stress & 1 & 2 & 3 & 4 & 5 \\
\hline & & 2. minimize injury & 1 & 2 & 3 & 4 & 5 \\
\hline & & 3. minimize bruising & 1 & 2 & 3 & 4 & 5 \\
\hline & f. & $\begin{array}{l}\text { Training farm personnel in cattle behavior and } \\
\text { handling techniques. }\end{array}$ & 1 & 2 & 3 & 4 & 5 \\
\hline
\end{tabular}

\section{Please check the response that best represents your answer to each question.}

10. Are you aware of Hazard Analysis Critical Control Points (HACCP), relating to the food industry?
a. Yes
b. No 
11. Should all treated animals be individually identifiable?

a. Yes

b. No

12. Vaccination instructions are just guidelines and do not have to be followed exactly.

a. True

b. False

13. Do you feel that it is important to follow recommended drug withdrawal times?

a. Yes

b. No

14. What is the least desirable route to give injections?

a. Intramuscular (IM)

b. Subcutaneous (SQ)

c. Intravenous (IV)

15. Injection site lesions are not permanent; they will disappear in a short amount of time.

a. True

b. False

16. What is the maximum vaccine dose that should be given per injection site?

a. $5 \mathrm{cc}$

b. $10 \mathrm{cc}$

c. $15 \mathrm{cc}$

d. $20 \mathrm{cc}$

17. How far apart should intramuscular (IM) injection sites be?

a. two fingers width

b. at least a hands width

c. multiple injections can be given at the same site

18. Where should intramuscular (IM) injections be given?

a. In the neck

b. Behind the shoulder

c. In the top butt

d. Anywhere is fine 
19. Which of the following will result in extra-label drug use and may require longer withdrawal times?

a. Administering more than the recommended dosage

b. Using a different route of administration than listed

c. Use of medication for a different species than listed

d. Use of a different gauge needle

e. A, B, and C

20. Do you have a market plan for culling and marketing cows?

a. Yes

b. No

21. Do you regularly consult your veterinarian about your animal health program?

a. Yes

b. No

22. Would you personally eat the meat from all of your market cows?

a. Yes

b. No

\section{Section 3: Quality Assurance Certification}

23. Are you currently certified in the West Virginia Dairy/Beef Quality (D/BQA) Program?

a. Yes (proceed to question 24)

b. No (skip to question 33)

24. When was the last time that you participated in a D/BQA training?

a. less than 1 year ago

b. 1-2 years ago

c. more than 2 years ago

25. Did you have an on-farm quality assurance plan before becoming certified?

a. Yes

b. No

26. Have you made any changes to your handling facilities since the D/BQA training?

a. Yes

b. No

c. Changes planned in the next 12 months 
Please list all handling facility changes planned and/or completed since the D/BQA training.

Completed

1 .

2.

27. Have you made any changes in your animal handling practices as a result of D/BQA training?

a. Yes

b. No

c. Changes planned in the next 12 months

Please list all changes in animal handling practices planned and/or completed since the D/BQA training.
1.

2.

28. Have you made any changes in your drug management practices as a result of D/BQA training?

a. Yes

b. No

c. Changes planned in the next 12 months

Please list all changes in drug management practices planned and/or completed since the D/BQA training.

Planned

1.

2 .

practices as a result of D/BQA training?
Completed

1.

2.

Planned
Completed Planned

1.

2 .

1.

2.

29. Have you made any changes in your recordkeeping practices as a result of D/BQA training?

a. Yes

b. No

c. Changes planned in the next 12 months

Please list all changes in your recordkeeping practices planned and/or completed since the D/BQA training.

\section{Completed}

1.

$$
2 \text {. }
$$

2.
Planned

1.

2. 
Instructions: Using the following scale, rate each instruction technique used in the D/BQA training: 1 Highly In-effective, 2 - In-Effective, 3 - Neutral, 4 - Effective, and 5 - Highly Effective.

\begin{tabular}{|c|c|c|c|c|c|}
\hline \multirow{2}{*}{$\begin{array}{l}\text { 30. Rate your preference of the following presentation } \\
\text { methods. }\end{array}$} & \multicolumn{5}{|c|}{ Level of Effectiveness } \\
\hline & 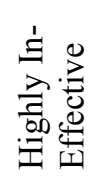 & 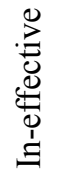 & $\begin{array}{l}\bar{\pi} \\
\overline{0} \\
\bar{Z}\end{array}$ & 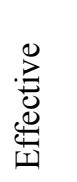 & 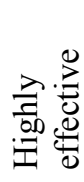 \\
\hline a. Slide presentation & 1 & 2 & 3 & 4 & 5 \\
\hline b. Calf necropsy & 1 & 2 & 3 & 4 & 5 \\
\hline c. Chute-side training & 1 & 2 & 3 & 4 & 5 \\
\hline
\end{tabular}

31. Have you noticed or do you foresee any market advantages relative to D/BQA certification?

a. Yes

b. No

If so, please list the market advantages relative to certification as you perceive them.

32. Is the D/BQA program something you will continue to participate in?

a. Yes

b. No

If no, why not:

33. Any additional questions or comments:

Thank you for taking the time to fill out this survey! Please remember to mail back your responses in the self addressed postage paid envelope that was provided. 
APPENDIX E

Comments to Question 32 
Question \# 32. Please list the market advantages relative to D/BQA certification as you perceive them.

"My goal is to produce more and better quality milk and meat."

"Better pricing."

"More money for calves, better quality calves."

"Premium for calves."

"Pool pricing should reflect some of knowledge we've learned through the programs."

"I think you will see the public will have a better feeling about the meat they eat."

"Have not seen any advantage to date. Hope this changes."

"Allows us to list them on the market sheet for our sold calves."

"This will give consumers an idea of where there meat comes from."

"BQA should make all parties to the production, feeders, and slaughter equation happier."

"It gets subpar programs up to a good control level, making more cattle desirable and uniform."

"Better prices and a lot better product."

"Will increase money as the cattle industry moves from average price to a value based market."

"Animals are more trusted as healthy."

"Animals are treated and handled in a proper way, resulting in lower stress."

"More confidence from consumers about the meat that they buy which will increase marketing ability."

"Healthier cattle and more money per pound on calves."

"The BQA price difference is obvious but we need to get this above a pure "commodity sale."

"Higher price for cattle." 
"Better return from buyer because they know that they are getting a better product (calves)."

"Make herd health better."

"Better quality calves, higher price per pound."

"Records so I have proof that when the animal left my farm it was safe."

"Strengthening consumer confidence in beef with a commitment to beef quality and safety."

"Shots given at special sales. Calves have been selling better. Buyers have less sickness and /or recover quicker."

"I think it will become a big issue in the future and it makes us all think before we do."

"Producer certification of BQA practice toward food (beef) safety issues."

"Better cattle prices, healthy calves going to market."

"Today the BQA calves bring more money as a group."

"Producer should see a premium for BQA practices at the time of sale."

"Healthier calves."

"Buyers pay more for them."

"Age-20 month-Japanese market."

"Feeders are becoming less tolerant of sick calves thus they are willing to buy and pay more calves that are BQA certified."

"To certify your product and provide documentation to the buyer-consumer."

"I haven't seen any market advantage yet. But as more farmers participate the livestock will probably put a premium through prices paid to producers."

"Packers want proof the animals are drug free."

"Price increase plus extra weight gain."

"Potential for source verified markets, continued increase in beef demand and consumer confidence." 
"Marketability of meat animals-carcass quality and antibiotic free."

"We see no change, we have always followed directions." 
APPENDIX F

Comments to Question 33 


\section{Question \#33. Any additional questions or comments.}

"There are very few health problems in my herd because I practice managementintensive grazing."

"I am 75 years old. I read the label on the drugs I use and administer the recommended dosage where it goes. I do what the vet recommends."

"My job is very hard but I really like it."

"D/BQA? Who remembers? More info. and more info. Can't keep up!"

"I use all D/BQA records. I do monthly vet herd checks. I have milk tested before it goes into the tanks. I do Johne's testing and am free. I have an all registered herd."

"We are a very small farm. Just a hobby to keep pasture down and have beef to butcher for family use."

"Would like to have more information on variables to track to determine and compare yearly performance of grazing cattle."

"I do not feel your id number should be given to any other agency."

"Get out of the angus association hip pocket. Quit ignoring the advantage of hybrid vigor."

"BQA should be here to stay. I think the big cattle buyers will demand it. A lot less sickness and loss with these cattle."

"Involved in KY CPH 45 program. Calves were sold on Nov. 10, they did real well, our area had around 50 to 55 thousand pounds."

"I think that this program and its training should be something all producers should participate in."

"Just starting back in the business. Rely on vet for vaccines, medication, etc."

"Send free information available on these questions."

"We still have much work on BQA training and we also need to really work the sale side of BQA animals. BQA animals should be at least 50 cents premium over nonBQA.”

"I received my BQA number from $\mathrm{KY}$ to sell on $\mathrm{CPH} 45$ sales. I and others from Wayne Co. went through the classes in WV for our BQA number but never received them. The third part of the certification was done on my farm around five years ago 
with approximately fifty people in attendance and forty head of cattle. Phil Osborne attended."

"Keep promoting the BQA. I prefer the sub-q. I've kept good records all along."

"D/BQA availability, communication, publication, requirements for participation etc. are lacking!! No mailings!"

"No premium for weaning, vaccinating calves returned to farm from local sales."

"I went to one program-they did not have enough material to give out. I was supposed to have been sent material and over 1 year has passed and still nothing. If that is what the programs are like, it is a waste of my time."

"There must be law passed for a large animal vet in each county, for an animal practice to have one large vet a time. Don't put meat on plates. If we are to have a BQA we must have vet to have recommended best management practice to meet industry quality challenges. We have no large animal vet in Wood county. We need a vet."

"D/BQA program needs to offer more dates instead of only one if you must do each year. Should be at least two years in between requirements."

"I like my beef on grass and grain, no growth hormones, steroids, or chicken litter."

"Very important and effective program for all cattle producers."

"The calves from our calf pool should be acceptable to all world markets."

"We direct market beef and are waiting to see what USDA will do about ID program."

"We buy calves in Oct. and sell the next Aug."

"This is a small family farm 8 breed cows, 15 goats, and some chickens. We farm to feed our family. It seems that all the government wants to do is run the small family farm out of business."

"I purchased the crossbow medidart system for injections without catching the animals. Used 1 time."

"With animal id coming soon, BQA procedures and certification will increase dramatically in importance."

"When is the next class to continue certification process?"

"More local training in beef quality assurance." 
"Administration \& recordkeeping too time consuming. The average small farmer has little time."

"Suggest you throw out my survey if response rate is low, my answers are linked to nine plus years of involvement with BQA."

"I think this survey is a waste of my time and none of your beeswax."

"A program is as good as the farmer using it." 
VITA

\section{Andrea L. Flanagan}

November 2006-Present

January 2006-December 2006

May 2003-May 2004

December 2005

May 2006
Pesticide Inspector

WV Department of Agriculture

Charleston, WV

Graduate Research Analyst

Animal \& Veterinary Sciences

Supervisor: Dr. Phillip Osborne

West Virginia University

Morgantown, WV

Undergraduate Research Analyst

Plant and Soil sciences

Supervisor: Dr. William Bryan

West Virginia University

Morgantown, WV

Bachelor of Science in Agriculture

Animal and Veterinary Science

West Virginia University

Morgantown, WV

Master of Science

Agricultural \& Extension Education

West Virginia University

Morgantown, WV 